\author{
UNIVERSIDADE DE SÃO PAULO \\ FACULDADE DE FILOSOFIA, LETRAS E CIÊNCIAS HUMANAS \\ DEPARTAMENTO DE LETRAS CLÁSSICAS E VERNÁCULAS \\ PROGRAMA DE PÓS-GRADUAÇÃO EM FILOLOGIA E LÍNGUA PORTUGUESA
}

\title{
A INSERÇÃO DO SE EM SENTENÇAS NÃO-FINITAS DO PB
}

\author{
por \\ ANDREA COLSATO
}

Dissertação apresentada à Coordenação de PósGraduação do Departamento de Letras Clássicas e Vernáculas da Universidade de São Paulo como requisito parcial para a obtenção do título de Mestre em Filologia e Língua Portuguesa.

Orientadora: Profa. Dra. Marilza de Oliveira

\section{SÃO PAULO}

2007 
É difícil entender os caminhos intricados nos quais enveredamos nossas escolhas. Entretanto, com muita segurança, posso dizer que tudo o que tem gerado motivação em mim nesses últimos anos vem daqueles que por mim foram gerados:

meus filhos.

A eles dedico este trabalho. 


\section{AGRADECIMENTOS}

Sou muito grata, antes de tudo, à minha orientadora Prof ${ }^{\mathrm{a}} \operatorname{Dr}^{\mathrm{a}}$ Marilza de Oliveira, que além de uma pesquisadora competente, inteligente e perspicaz é, sem dúvida, uma pessoa incentivadora e generosa.

Às profas. Dr ${ }^{\mathrm{a}}$ Maria Célia Lima-Hernandes e Dr ${ }^{\mathrm{a}}$ Maura Alves de Freitas Rocha, que compuseram minha banca de qualificação, pelas inúmeras contribuições relativas ao conteúdo deste trabalho.

À banca examinadora, pela atenção dada ao meu trabalho e pela boa vontade em compartilhar conhecimentos.

Aos funcionários do Departamento de Clássicas e Vernáculas, pelos inúmeros serviços prestados com a mesma gentileza de sempre.

À direção da Escola Graduada, por permitir a conciliação de minhas atividades profissionais e acadêmicas.

Aos meus amigos da pós, que sempre estiveram ao meu lado dispostos a discutir textos e compartilhar idéias, mesmo envoltos com tantos outros compromissos.

Aos meus amigos da Graduada, com quem compartilhei boa parte do tempo que este trabalho tomou, dando boas risadas nas angústias e dificuldades.

Aos meus tantos outros amigos que ficaram distantes, cuja resignação agradeço, pois entendo que a amizade, assim como o amor, são cultivados no dia-a-dia.

À minha mãe, que sempre me mostrou com suas atitudes que podemos superar percursos difíceis mesmo em situações adversas.

Aos meus filhos Nathália, Vitória e Gabriel, motivações constantes de minha vida.

Ao Jandui pelo seu companheirismo, tolerância e sensibilidade. 
"Aprendi (...) a transformar o medo em respeito, o respeito em confiança.

Descobri como é bom chegar quando se tem paciência. $\mathrm{E}$, para se chegar, onde quer que seja, Aprendi que não é preciso dominar a força, mas a razão.

É preciso, antes de mais nada, querer."

"Cem dias entre céu e mar", Amyr Klink 


\section{PRÓlogo}

O trecho de Amyr Klink, do livro Cem dias entre céu e mar, parece resumir o que esta dissertação significou nesses mais de cem dias de elaboração. Dois são os motivos que tornam o fragmento significativo. O primeiro deles refere-se ao sujeito; o segundo, ao objeto. Explico: quem elaborou o quê? Vamos a eles.

Quem poderia comparar o trabalho de um velejador com o de um pesquisador? Apesar de não parecer, esses dois profissionais têm muito em comum. Só quem está perto, quem vivencia o dia-a-dia desses aventureiros pode entendê-los e saber ao certo o que fazem, as suas dificuldades e anseios. O velejador abraça um ideal, o de transpor com seu pequenino barco o infindável mar, mar que já foi tema para grandes escritores da língua, de Camões a Fernando Pessoa, ao retratar as angústias de viajantes, seus medos, seus mitos. O mar é uma imensidão, assim como é a língua estudada pelo lingüista, imensa, infindável, com seus meandros tenebrosos, confusos. A língua de certa forma é o mar. A sua vastidão. A sua complexidade. O fragmento de Amyr Klink assim revela, e revela mais, a paciência e obstinação do pequeno viajante face ao incomensurável. É preciso respeitar o mar, é preciso conhecê-lo, é preciso ter paciência para descobri-lo. Pois assim é o trabalho do lingüista. "Não é preciso dominar a força, e sim, a razão", esta é a premissa de qualquer velejador da linguagem.

Quanto ao meu objeto de estudo, o trecho tem mais a dizer, não sobre o mar ou o trabalho do velejador, mas sobre a própria língua: “ Descobri como é bom chegar quando se tem paciência. E, para se chegar..." "Se chegar"? O que significaria esse se antes do verbo chegar? Seria a indagação do pesquisador? O se da hipótese? Não seria apenas “chegar”? Que raios de Poseidon a palavra se está fazendo nesta sentença? Seria obra dos

céus? Seria embriaguez do velejador? Não. É a língua quebrando no mar, suas ondas, suas facetas, suas novas nuances.

Sobre a inserção deste se é o trabalho que se apresenta. 


\section{RESUMO}

Este trabalho tem por objeto de estudo um fenômeno do português do Brasil mais comumente encontrado em textos formais. Trata-se do pronome fraco se precedendo verbos infinitivos. Esse item compete com zero na indeterminação do sujeito em orações encaixadas, mais precisamente em orações completivas de nome e adjetivo, temporais e finais.

Propõe-se descrever os fatores condicionadores da inserção do se em sentenças nãofinitas do português brasileiro e promover um análise da questão à luz da teoria gerativa no seu modelo de Princípios e Parâmetros (Chomsky 1981, 1986a).

Tomou-se como corpus textos formais de alunos da pós-graduação de diversas áreas do conhecimento da Universidade de São Paulo, hipotetizando que o teor científico do texto proporcionaria a estratégia de indeterminação por nós analisada. Em seguida, foram elaborados testes de produção junto aos alunos da graduação dessa mesma universidade a fim de verificar se as respostas produzidas por eles corroborariam os resultados encontrados nas dissertações e teses.

Dentre os fatores mais relevantes para justificar a inserção de se nas construções com verbos infinitivos, destacou-se a preposição. Para a análise interpretativa desse achado, seguimos a proposta de Mioto \& Kato (2002).

PALAVRAS-CHAVE: inserção de se, preposição, complementizador, indeterminação, transitividade. 


\begin{abstract}
This dissertation aims at studying a Brazilian Portuguese phenomenon commonly found in formal texts. It is the se insertion as subject of infinitive clauses. This particle competes with the null category in the subject indetermination in embedded clauses, more precisely in the complement of noun and adjective clauses and clauses of time and finality.

It is intended to describe the conditioning factors of the se insertion in non-finite sentences from Brazilian Portuguese and promote an analysis of the matter having the Generative Theory in its model of Principles and Parameters (Chomsky 1981, 1986a) as a reference.

At first, it was used as corpus formal texts by graduate students from different areas of knowledge from Universidade de São Paulo, hypothesizing that the text scientific wording would allow the strategy of the indetermination analyzed in this dissertation. Secondly, production tests were elaborated with undergraduate students from the same university in order to verify if the answers produced by them would confirm the results found in the dissertations and theses.

Among the most relevant factors to justify the se insertion in the constructions with infinitive verbs, the preposition stood up. For the interpretative analysis, we followed Mioto \& Kato (2002) proposal.
\end{abstract}

KEY WORDS: se insertion, preposition, complementiser, indetermination, transitivity 


\section{SUMÁRIO}

PÁGINAS

RESUMO

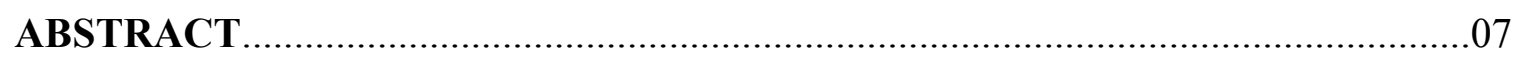

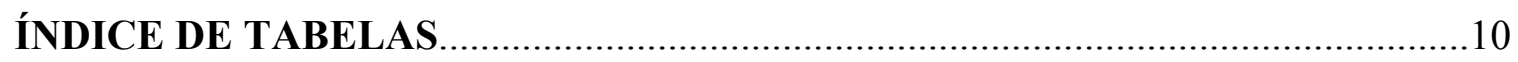

i. INTRODUÇÃO

i.1. A ESTRUTURA [SE + VERBOS NÃO- FINITOS] ..............................................13

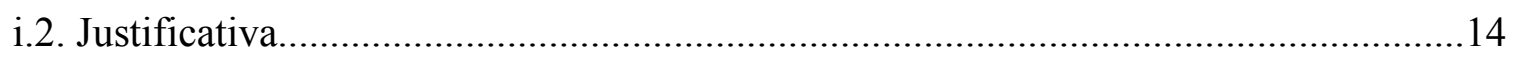

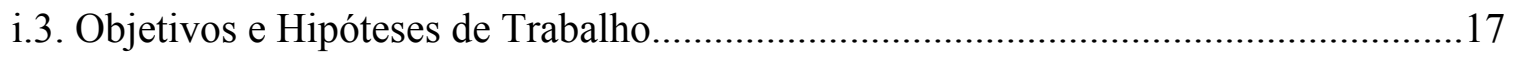

\section{CAPÍTULO I}

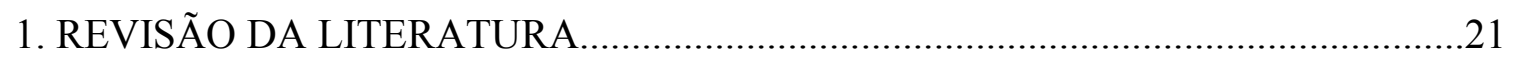

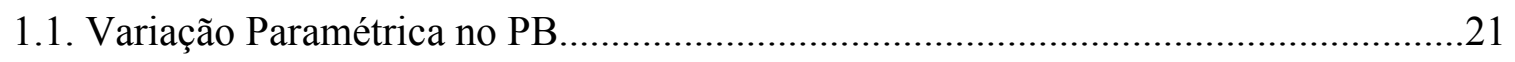

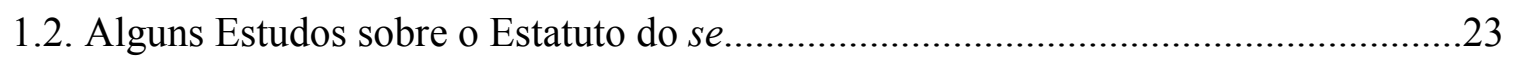

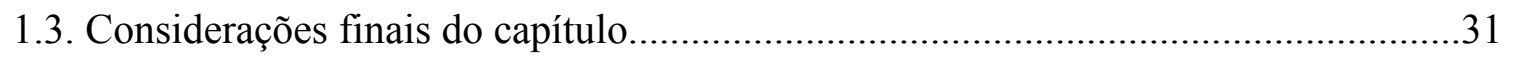

\section{CAPÍTULO II}

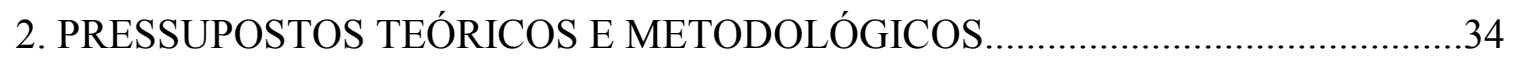

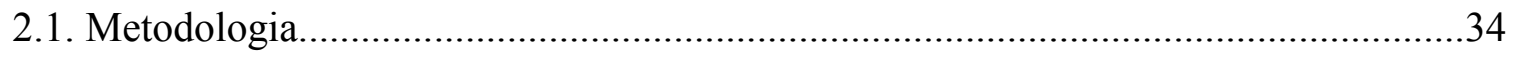

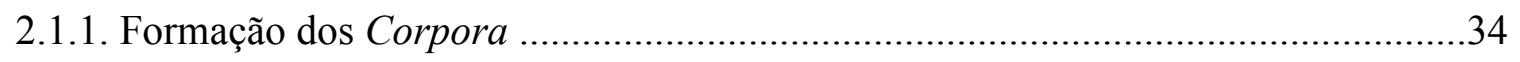

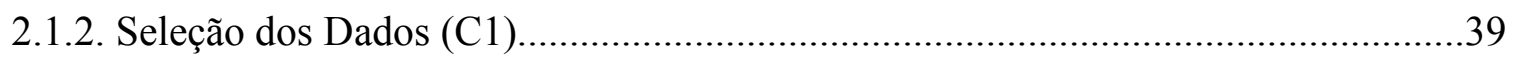

2.1.3. Grupos de Fatores....................................................................................... 40

2.1.4. Testes de Produção ...........................................................................................42 


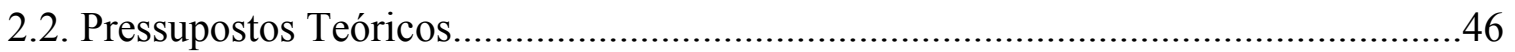

2.2.1. Categoria Vazia PRO e Teoria da Ligação................................................................46

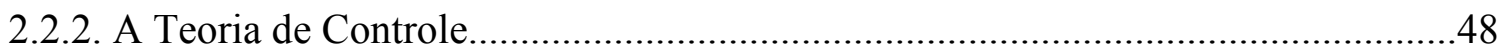

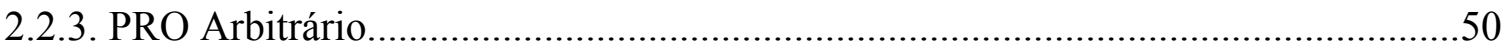

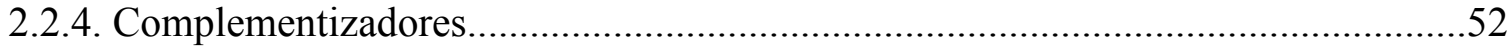

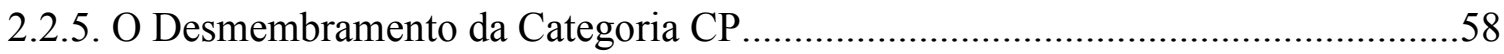

2.2.6. Preposições Lexicais e Funcionais na Subordinação Sentencial..............................62

\section{CAPÍTULO III}

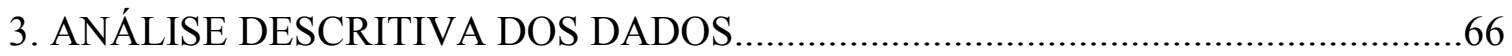

3.1.Fatores para aposição de se em estruturas biargumentais e monoargumentais

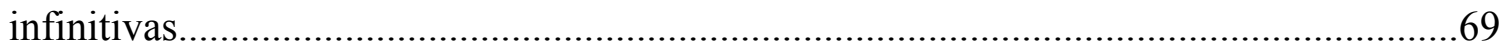

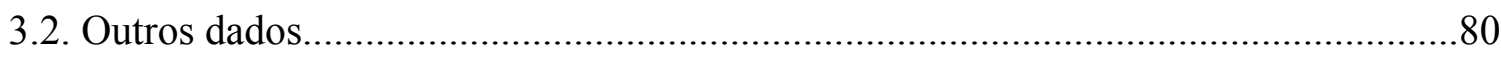

3.3. Considerações finais do capítulo................................................................................ 83

\section{CAPÍTULO IV}

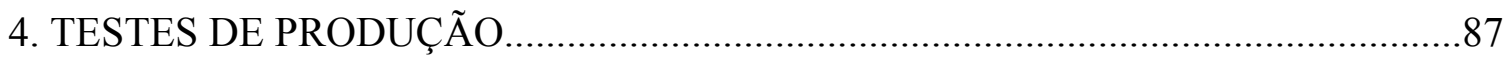

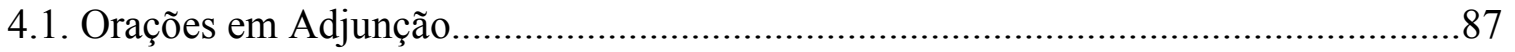

4.2. Orações Completivas de Nome e Adjetivo..................................................................91

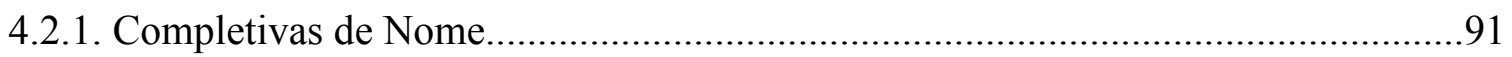

4.2.2. Completivas de Adjetivo..................................................................................96

4.3. Considerações finais do capítulo........................................................................100

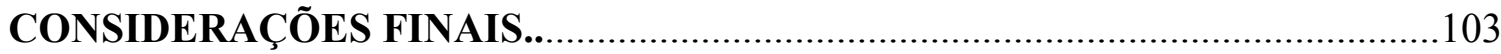

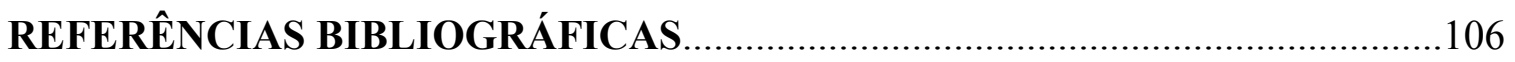




\section{ÍNDICE DE TABELAS}

PÁGINAS

Tabela 1 - Estrutura Argumental dos Verbos.............................................................68

Tabela 2 - Presença X Ausência de Preposição.................................................................

Tabela 3 - Distribuição das Preposições X Estrutura Argumental dos Verbos..................72

Tabela 4 - Antecedente da Preposição ‘de’ X Estrutura Argumental do Verbo .............74

Tabela 5 - Antecedente da Preposição 'para' X Estrutura Argumental do Verbo............75

Tabela 6 - Antecedente da Preposição ' $a$ ’ X Estrutura Argumental do Verbo..................76

Tabela 7 - Tipos de Orações X Estrutura Argumental do Verbo........................................79

Tabela 8 - Distribuição das Orações quanto à Referencialidade da Matriz.......................87

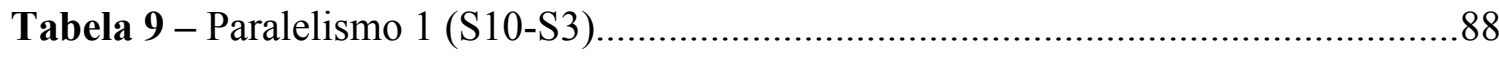

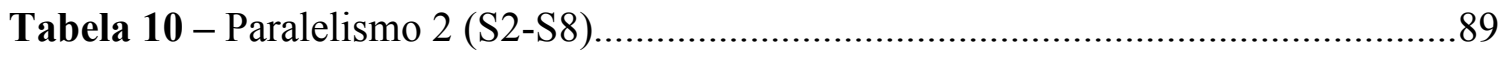

Tabela 11 - Paralelismo 3 (S5-S11) ......................................................................90

Tabela 12 - Preenchimento por Preposição (S4-S13).....................................................92 
Tabela 13 - Preenchimento da Posição de Sujeito (S9)

Tabela 14 - Preenchimento da Posição de Sujeito (S4)................................................94

Tabela 15 - Preenchimento da Posição de Sujeito (S13) .............................................95

Tabela 16 - Estratégias de Indeterminação (S9-S4-S13) ............................................96

Tabela 17 - Preposição X Preenchimento do Sujeito (S12).........................................97

Tabela 18 - Preenchimento da Posição de Sujeito (S6)...............................................98

Tabela 19 - Estratégias de Indeterminação (S12-S6) ..............................................99 
i. INTRODUÇÃO 


\section{i. INTRODUÇÃO}

Este trabalho tem por objeto de estudo um fenômeno do português do Brasil (doravante, PB) mais comumente encontrado em textos formais. Trata-se da inserção do pronome fraco se precedendo verbos infinitivos (V-FIN). Esse item vem competindo com zero na indeterminação do sujeito em orações encaixadas, constituindo um elemento de referência arbitrária.

\section{i.1 A ESTRUTURA [SE + VERBOS NÃO-FINITOS]}

Galves (1987) e Nunes (1990), entre outros, apontam o apagamento do clítico se em sentenças finitas e a sua inserção em sentenças não-finitas como mudanças concomitantes do PB atual. Enquanto na maioria das sentenças finitas há a tendência à não realização do clítico, nas sentenças não-finitas, o se vem gradativamente se impondo:

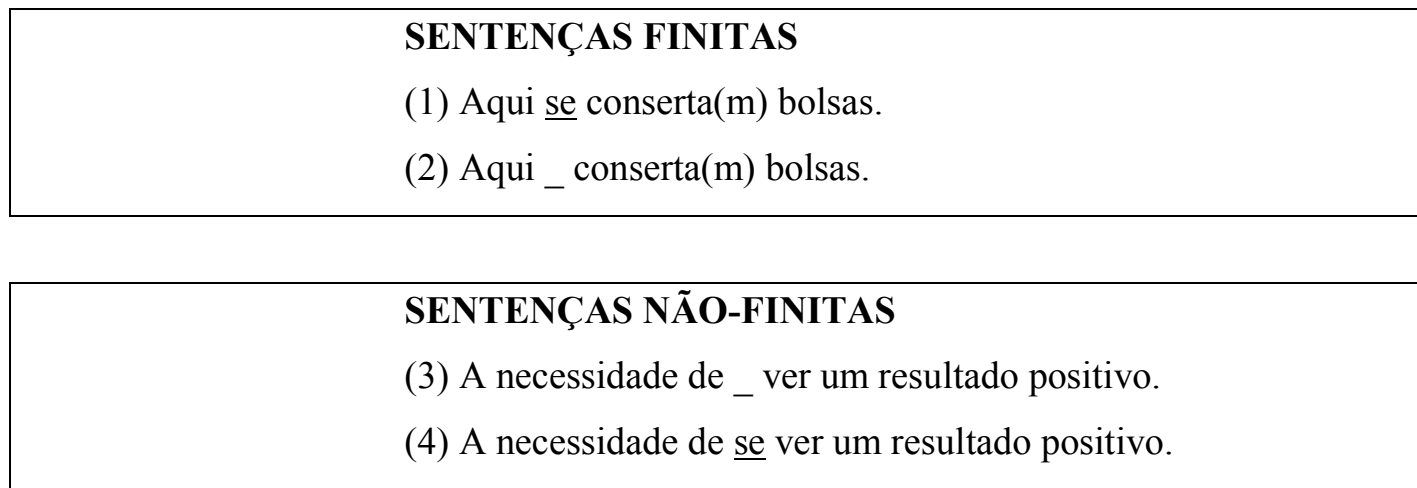

O usuário da língua estaria trocando estruturas como (1), na qual o se aparece, por estruturas como (2), sem o se; assim como estaria trocando estruturas como (3), na qual o uso do se não era observado, por estruturas como (4), agora, com o uso do se. Tal 
mudança, aparentemente contraditória, parece ser uma mudança encaixada ${ }^{1}$ no sistema, ocorrendo junto a uma série de outras mudanças ${ }^{2}$ de reorganização da língua.

$\mathrm{O}$ interesse que esse assunto desperta deve-se à não coincidência da inserção contemporânea de tal partícula com as prescrições da gramática normativa (GT). Segundo Said Ali (1964), o infinitivo impessoal [V-FIN] é utilizado quando a intenção é de se indeterminar o sujeito. Nesse caso, a posição pré-verbal apareceria não marcada, como em (3).

Entretanto, o que se observa na frase (4) é que o falante do PB está reinterpretando o V-FIN como uma forma verbal passível de carregar o sujeito indeterminado, marcado por se. Tal utilização expressa não só um desvio do $\mathrm{PB}$ em relação à prescrição gramatical, como também uma possibilidade não encontrada em nenhuma outra língua românica. A pergunta que se coloca, então, é: por que está havendo esta reinterpretação? E ainda, quais são os fatores desencadeadores de tal mudança?

\section{i.2. JUSTIFICATIVA}

O trabalho de Nunes (1990) sobre as construções com se junto a verbos flexionados $(\mathrm{V}+\mathrm{FIN})$ mostra que o $\mathrm{SN}$ posposto nas passivas pronominais está sendo reinterpretado como objeto direto, portador de $\mathrm{Caso}^{3}$ acusativo e não mais como sujeito, portador de Caso nominativo e responsável pela concordância. O falante troca estruturas como (5) por estruturas como (6):

(5) Vendem-se casas.

(6) Vende-se casas.

Conforme terminologia empregada por Naro (1976), o sintagma nominal posposto em concordância com o verbo resultaria em uma construção passiva, já o sintagma

\footnotetext{
${ }^{1}$ Weinreich, Labov \& Herzog 1968.

${ }^{2}$ Citamos aqui a reorganização do paradigma pronominal e o preenchimento do sujeito.

${ }^{3}$ Caso, em letra maiúscula, é de natureza estrutural e não morfológica.
} 
nominal posposto sem concordância estabeleceria uma construção de indeterminação. Em se tratando de uma construção passiva, o SN posposto seria interpretado como sujeito, possuidor de Caso nominativo; o SN posposto, na construção de indeterminação apresentaria Caso acusativo e seria interpretado como objeto direto. O quadro a seguir apresenta tal hipótese de interpretação da construção seV+FIN com verbos biargumentais ${ }^{4}$ :

\section{VERBO BIARGUMENTAL : [+ CONC] = ESTRUTURA PASSIVA$$
[-\mathbf{C O N C}]=\text { ESTRUTURA DE INDETERMINAÇÃO }
$$

Observemos, agora, os exemplos de se em estruturas [-FIN]:

(7) (...) pela dificuldade de se estabelecer o pensamento da vítima.

(8) (...) a dificuldade de se estabelecer pontes com os demais colegas.

Em situação paralela às estruturas finitas, nas sentenças [-FIN], o SN posposto parece nem sempre estabelecer concordância com o verbo. $O$ verbo infinitivo não sofre flexão e o sintagma nominal posposto ao verbo ora aparece no singular, ora no plural. Nesse caso, poderíamos, por analogia, considerar o exemplo (7) como uma estrutura de passiva, e o exemplo em (8) como uma estrutura de indeterminação. O verbo presente nos exemplos é transitivo direto, qualidade que reafirmaria a possibilidade da formação da passiva, se ocorresse a presença da concordância verbal.

Ao estudar estratégias de indeterminação em sentenças [-FIN], Duarte (2002) hipotetiza que, ao contrário do que se observa nas sentenças [+FIN], o usuário da língua estaria trocando estruturas de indeterminação por estruturas passivas. A autora toma como evidência a marca de concordância no plural com o argumento posposto. Voltaremos a essa discussão no capítulo I.

Comparemos, agora, com as estruturas passivas perifrásticas abaixo:

\footnotetext{
${ }^{4}$ Em Mioto (2005), verbos biargumentais são aqueles que apresentam dois argumentos: o interno e o externo.
} 
(7a) (...) o pensamento da vítima ser estabelecido.

(8a) * pontes com os demais colegas ser estabelecido.

(8b) (...) pontes com os demais colegas serem estabelecidas.

O exemplo em (7a) é perfeitamente aceitável, formando par correlato com a passiva pronominal em (7). No entanto, (8a) parece ser um tipo de construção não muito freqüente do português brasileiro. Vejamos que o verbo teria de ser flexionado em (8b) para estabelecer concordância com o sintagma nominal pré-verbal, tornando a construção mais aceitável do ponto de vista normativo.

Continuando a analogia estabelecida entre estruturas com verbos finitos e nãofinitos, o que talvez possa explicar a agramaticalidade de (8a) seja, conforme sugere Naro (1976), que estruturas passivas (com ou sem concordância) estão sendo reanalisadas como estruturas ativas. O pesquisador apresenta três argumentos para a ocorrência desse fenômeno de reanálise. O primeiro deles diz respeito à morfologia da língua. No português, como não existe uma morfologia marcada de singular, não haveria uma forma de diferenciação das estruturas passivas e ativas, portanto, o fato de a estrutura apresentar-se na $3^{\mathrm{a}}$ pessoa do singular não seria determinante para a sua classificação como passiva. A segunda explicação dada é que a estrutura não apresenta um agente expresso, forçando a interpretação do se como agente. Por último, a questão da fixação da ordem no português, o se em posição pré-verbal assumiria a posição prototípica de sujeito.

Quanto às construções com se V-FIN, as gramáticas históricas ${ }^{5}$ registram a possibilidade ou não de concordância, o que poderia levar a uma leitura passiva ou ativa. Resta saber se esse tipo de construção ocorre com verbos monoargumentais ${ }^{6}$, o que impediria a leitura passiva. É nesse contexto em que se insere este trabalho.

\footnotetext{
${ }^{5}$ Citamos Said Ali 1968.

${ }^{6}$ Segundo Mioto (2005), verbos monoargumentais são aqueles que apresentam apenas um argumento: o interno ou o externo.
} 


\section{i.3. OBJETIVOS E HIPÓTESES DE TRABALHO}

O objeto de estudo deste trabalho é o se com verbos não-finitos e tem por objetivo mapear as estruturas que o acolhem. Não trabalharemos a variação entre zero e se, pois na grande maioria dos casos é ainda o zero que predomina (cf. Cavalcante 1999, Duarte 2000). Nosso objetivo restringe-se, portanto, tão somente à análise das estruturas em que o se aparece.

Os questionamentos que permeiam esta pesquisa são:

1- Que tipo de estrutura argumental de verbo favorece o uso de $s e$ ?

2- Que categorias de palavras precedem o se na cadeia sintática?

3- Há contextos em que o se é obrigatório?

As hipóteses que norteiam a descrição e interpretação dos dados são as seguintes:

1- Tipo de verbo com o qual o se ocorre:

O se ocorre não só com verbos biargumentais, mas também com verbos monoargumentais. Esta hipótese se apóia nos resultados da análise do se em construções [+FIN] (Nunes 1990).

2- Reanálise:

A perda da concordância nas estruturas [+FIN] (conserta-se bolsas) leva à reanálise da sentença passiva em ativa (Naro 1976), igualando essa estrutura à das sentenças ativas com verbos monoargumentais (vive-se bem). $\mathrm{O}$ mesmo ocorre nas estruturas $[-\mathrm{FIN}]$. 
3- Presença de preposição:

O se em construções V[-FIN] emerge em contextos em que uma preposição está presente (a importância de se conhecer o objeto de estudo).

Propõe-se a seguinte representação gráfica do fenômeno em análise:

$$
\text { [X Prep] se [V-FIN] }
$$

em que X pode ser Nome, Adjetivo ou simplesmente um elemento nulo. Indagase, ainda, qual a natureza da preposição (lexical ou funcional) que antecede o se.

\section{4- Referencialidade:}

A ocorrência de se na oração infinitiva relaciona-se com a presença de sujeito [-DET] na oração matriz; assim como a presença de Ø na oração infinitiva, relaciona-se com sujeito [+DET].

Das hipóteses acima, extrai-se a hipótese maior que norteia o trabalho: a natureza da preposição licencia a inserção de se em construções com verbos [-FIN]?

Em suma, este trabalho propõe-se a descrever os fatores condicionadores da inserção do se em sentenças não-finitas do $\mathrm{PB}$, e promover uma análise da questão à luz da teoria gerativa no seu modelo de Princípios e Parâmetros (Chomsky 1981). A justificativa que se impõe é a necessidade de uma análise criteriosa da estrutura na qual o se ocorre, e, para tanto, o tratamento dado ao fenômeno envolve uma análise estatística do corpus coletado a fim de detectar os grupos de fatores que atuam na estrutura se com verbos $[-$ FIN]

O trabalho está organizado da seguinte maneira. No primeiro capítulo, faremos uma revisão da literatura sobre o se. No capítulo II, explicitaremos os pressupostos teóricos e metodológicos nos quais esta pesquisa está assentada. Em seguida, no capítulo III, mostraremos os resultados da análise descritiva dos dados; e, no capítulo IV, procederemos à análise de testes realizados por alunos. Na medida do possível, 
procuraremos comparar os resultados desta pesquisa com as discussões elaboradas por Galves (1987), Nunes (1990), Cavalcante (2002), Duarte (1993, 2000) e Duarte e Lopes (2002), na expectativa de que a comparação possa elucidar a aparente contradição sobre o uso de se acenada na introdução deste trabalho. 


\section{REVISÃO DA LITERATURA}

\subsection{VARIAÇÃO PARAMÉTRICA NO PB}

O modelo de Princípios e Parâmetros formulado por Chomsky (1981,1986a) surgiu no âmbito dos estudos comparativos e abriu caminho tanto para estudos diacrônicos, como para a análise sincrônica entre línguas. Esse modelo entende a gramática universal $(\mathrm{GU})^{7}$ como sendo constituída por leis gerais válidas para todas as línguas naturais, chamadas de princípios; e parâmetros abertos, cuja fixação determina a diversidade lingüística.

Assunto amplamente discutido na literatura gerativista, o parâmetro do sujeito nulo (PSN) postula a existência de línguas nas quais o sujeito pode ser nulo nas sentenças finitas; e de outras línguas em que o sujeito deve ser marcado, mesmo que seja com uma partícula expletiva ou um expletivo nulo.

Em relação a esse parâmetro, o português do Brasil vem sendo considerado como uma língua em variação. Uma série de estudos diacrônicos ${ }^{8}$ mostra que o PB muda de uma língua pro-drop para uma língua não pro-drop, em outras palavras, deixa de ser uma língua de sujeito nulo e encaminha-se para uma língua de sujeito pleno.

A preferência pelo preenchimento do sujeito no PB, segundo Duarte (2000), devese a uma reorganização do sistema. A redução do paradigma flexional dos verbos está intimamente ligada à mudança no quadro pronominal do $\mathrm{PB}$, que antes exibia seis formas diferentes e, hoje, exibe apenas três:

"The reduction began with the replacement of the second person pronominal forms "tu", 2nd singular and "vós", 2nd plural, which combined with verb forms bearing exclusive inflections, with the former

\footnotetext{
${ }^{7} \mathrm{Na}$ teoria gerativa, compreende-se a linguagem como uma capacidade geneticamente herdada e propõe-se a existência de um estado mental inicial, chamado de GU, que torna possível a aprendizagem das línguas.

${ }^{8}$ Duarte (2000) cita os estudos de Tarallo 1983; Berlinck 1989, 1996; Duarte 1992, 1993; Lopes Rossi 1993; Torres Morais 1994; Ribeiro 1994; Cyrino, Duarte \& Kato 2000, entre outros.
} 
address form "você(s)", which combines with third person verb forms. More recently, the first person plural pronoun "nós" is being replaced by the pronominal expression "a gente", which also requires the third person singular verb form."

(Duarte 2000:18)

Assim, em sua pesquisa sobre a perda do princípio "Evite Pronome" no PB, a autora relata que, ao lado do sujeito referencial definido, há também uma nova distribuição do sujeito referencial arbitrário, que tende a ser preenchido. O resultado da análise de exemplos contemporâneos ${ }^{9}$ de estratégias de indeterminação mostrou que as formas pronominais expressas (66\%) são muito mais prevalentes que as formas nulas (34\%). E, ao contrário do que dita a gramática tradicional, o uso do clítico se como partícula de indeterminação é a forma menos freqüente.

As formas de indeterminação preferidas atualmente ${ }^{10}$ nas sentenças [+FIN] são você (44\%), seguida da terceira pessoa do plural eles (16\%), e da primeira pessoa do plural a gente (13\%), que juntas configuram (73\%) das ocorrências. Em seguida, vem o clítico se com forma verbal na terceira pessoa (8\%), em variação com zero também com forma verbal na terceira pessoa (17\%). Finalmente o uso de nós em apenas (2\%) dos exemplos de sujeito arbitrário, sugerindo uma tendência similar com o observado para sujeitos referenciais definidos. Ressalte-se aqui o baixo índice percentual de se como sujeito indeterminado de verbos finitos.

Segundo a autora, o empobrecimento do paradigma flexional dos verbos teria acionado o preenchimento de sujeitos referenciais pronominais determinados e indeterminados, bem como o desenvolvimento de novas estratégias de preenchimento de sujeitos não-referenciais.

\footnotetext{
${ }^{9}$ Os dados são parte da amostra Recontato/NURC-RJ, gravados em 1992. Constam, ainda, quatro horas de gravação de entrevistas de rádio com pessoas de diferentes regiões do Brasil.

${ }^{10} \mathrm{~A}$ autora utilizou o mesmo corpus.
} 


\subsection{ALGUNS ESTUDOS SOBRE O ESTATUTO DO SE NO PB}

Nesta seção, apresentamos alguns estudos sobre o se no PB. Inicialmente, o trabalho de Galves (1987), que primeiro vislumbrou a inserção do se em sentenças [-FIN]. Em seguida, Nunes (1990), que executou uma extensa investigação sincrônica e diacrônica do estatuto do se em sentenças finitas e infinitivas. Desdobramentos destes, o trabalho de Cavalcante (2002) sobre formas de indeterminação na imprensa carioca dos séculos XIX e XX, e o trabalho de Duarte (2000) sobre construções com se apassivador e indeterminador em anúncios do século XIX. Por fim, a análise de Duarte e Lopes (2002) sobre a indeterminação do sujeito com três formas pronominais nas sentenças [+FIN] e a variação entre $\varnothing$ e se nas sentenças [-FIN].

Galves (1987) observa a existência de uma sintaxe brasileira muito claramente distinta da sintaxe portuguesa, ao considerar a existência de uma

estranha diferença entre o PE e o PB: enquanto neste o se tem nítida tendência a desaparecer da língua em todos os seus usos nas frases com tempo, ele reaparece maciçamente - distanciando-se nisso do uso do PE-, nas infinitivas, para expressar a indeterminação(p.46).

A autora estabelece o seguinte quadro comparativo entre o PB e o PE (português europeu):

\section{Indeterminação nas Infinitivas}

\begin{tabular}{|ll|}
\hline PB & $\begin{array}{l}\text { É impossível se achar lugar aqui. } \\
\text { É impossível_achar lugar aqui. }\end{array}$ \\
\hline PE & O João é difícil de $s e$ convencer. \\
PB & O João é difícil de _ convencer. \\
\hline
\end{tabular}


Galves julga a questão do se central para começar a delinear os sistemas do PB e do PE no que diz respeito à expressão da referência. Nesse sentido, a interpretação das categorias vazias seria o componente mais revelador da diferença entre esses dois sistemas. A autora explicita que no PE o sujeito nulo determinado nas infinitivas é interpretado como coindexado com um antecedente da sentença; caso não se observe a coindexação, tem-se a interpretação indeterminada. Já o PB aceitaria dois possíveis antecedentes para o sujeito nulo das infinitivas, ou um antecedente no discurso (tópico) ou antecedente na sentença, deixando ao contexto a tarefa de desfazer a ambigüidade da interpretação.

Para além do contexto, no PB observa-se uma nova forma de desfazer a ambigüidade, trata-se da emergência do se indeterminador nas sentenças [-FIN]. Essa estratégia impede que o sujeito seja referencialmente vinculado ao tópico. Vejamos como se daria o processo:

(9) "Maria ${ }_{\mathrm{i}}$ acha melhor $c v_{\mathrm{i} j}$ ler a carta."

No PB, a primeira possibilidade de interpretação para a sentença seria que a Maria acha melhor a Maria (ela mesma) ler a carta, coindexando a posição vazia ao sujeito expresso na primeira oração. Numa segunda interpretação, a Maria acha melhor "a Joana" ler a carta. Nesse caso, o antecedente estaria no discurso (tópico), e não na sentença e não haveria o vínculo com o sujeito expresso na primeira oração.

O se surge, nesse contexto, para impedir que o sujeito seja referencialmente vinculado ao tópico.

(9a) "Maria acha melhor se ler a carta."

Galves afirma que, a partir do trabalho de Pontes (Apud Galves 1987), tem-se reconhecido o PB como uma língua de tópico, "porque permite a ocorrência de um sintagma nominal separado da sentença, retomado ou não em seu interior por um pronome-cópia". Nesse sentido, a autora interpreta o surgimento do se em construções infinitivas como uma construção mais freqüente nas línguas de organização tópico- 
comentário, como o chinês, do que a sintaxe das línguas sujeito-predicado, como o inglês.

O uso do se com verbos [-FIN] decorreria de um quadro maior de mudanças que vêm ocorrendo no $\mathrm{PB}$. A redução no quadro flexional causaria o aumento do preenchimento do sujeito e, em virtude disso, o aumento no uso do se para marcar indeterminação.

Nunes (1990) opera uma descrição bastante detalhada do percurso do clítico se em textos de 1555 a 1989. O autor assinala como uma forma inovadora a inserção do se em sentenças [-FIN], assim como seriam inovações a elisão do clítico se em sentenças finitas e a preferência pela discordância entre o verbo e o argumento interno. As diversas mudanças envolvendo se apassivador e se indeterminador no PB foram analisadas em função da mudança que substitui construções como (10) por construções como (11), e da mudança que substitui estruturas como (12) por estruturas como (13):

(10) Alugam-se casas.

(11) Aluga-se casas.

(12) Aqui se conserta sapatos.

(13) Aqui _ conserta sapatos.

Para o autor, as mudanças envolvendo se indeterminador no PB, como seu apagamento em sentenças finitas e sua inserção em sentenças não-finitas, somente tiveram início quando as construções com se indeterminador se tornaram mais freqüentes que as construções com se apassivador. Esta constatação ratifica o trabalho de Naro (1976), que admite não existir dúvidas sobre a cronologia histórica do se indeterminador:

$O$ se passivo, com concordância e sintagma agentivo precede o se impessoal, sem concordância e sintagma agentivo. A construção com se impessoal é uma inovação relativamente recente, primeiro ocorrendo em textos de meados do século XVI e baseada na construção clássica sepassiva. 
Segundo Nunes (1990), houve uma reanálise da categoria vazia na posição de sujeito das passivas pronominais ${ }^{11}$. Assim, o fato de a categoria vazia passar a ser interpretada como um pronome referencial e não como um expletivo forçou a interpretação do SN posposto como objeto direto, portador de Caso acusativo, e não como sujeito, portador de Caso nominativo e responsável pela concordância verbal.

O autor, então, propõe uma análise unificada das construções com se apassivador e se indeterminador nas construções finitas. A superficialização de uma ou outra forma seria resultado da interação entre as propriedades lexicais do clítico se. Ao ser gerado sob INFL, se só poderia absorver o papel temático reservado ao argumento externo; enquanto clítico, se escapa ao Filtro dos Casos e só poderia absorver Caso acusativo para satisfazer o Princípio de Atribuição de Papel Temático.

Assim, o se apassivador absorveria papel temático de argumento externo e Caso acusativo e seria ligado por um elo da cadeia temática que envolve o argumento interno, indeterminando a referência do argumento externo. Sendo indeterminador, o clítico só teria necessidade de satisfazer seus traços [+ anáfora, - pronome], e seria ligado por um pronome referencial nulo, configurando, desta maneira, uma relação anafóricopronominal de referência indeterminada.

Segundo o autor, existem duas motivações para julgar que o se inserido nas estruturas infinitivas seja indeterminador. A primeira delas diz respeito à predominância, já no século XIX, de construções com se indeterminador, em detrimento a construções com se apassivador. A segunda, a presença de se em construções com verbos nãotransitivos ou estruturas transitivas em discordância verbal só poderiam estar associadas ao se indeterminador. A constatação parte da análise que, exatamente no século XIX, o PB passa a preferir a categoria pro para ocupar a posição de sujeito das infinitivas, ao invés de PRO. O autor mostra, segundo Cinque (apud Nunes 1990:112), que no italiano, como não há infinitivo flexionado, a posição de sujeito da oração encaixada é ocupada pelo elemento PRO. Por sua vez, no PB, sendo uma língua de infinitivo flexionado, ocorreria pro.

Outra contribuição para os estudos sobre a inserção do se foi a pesquisa de Cavalcante (2002) sobre as estratégias de indeterminação do sujeito na escrita padrão da

\footnotetext{
${ }^{11}$ Observe-se que o autor se refere às estruturas finitas.
} 
imprensa carioca no período entre 1848 a 1998, divididos em cinco períodos. O objetivo da pesquisa foi avaliar a gramática tradicional quanto à prescrição de uma norma ideal ou uma norma real da escrita padrão, e relacionar os resultados com o estabelecimento da norma culta no Brasil. A amostra foi composta por textos jornalísticos com três graus de formalidade: editoriais, artigos de opinião e crônicas. Suas três hipóteses foram o aparecimento discreto de novas formas pronominais de referência indeterminada ( $a$ gente, você), sem haver necessariamente um maior índice de sujeitos plenos, dado o caráter conservador da escrita; o crescente uso de se indeterminador nas estruturas [+FIN]; e, o crescente uso de clítico se com verbos [-FIN], cuja inserção no sistema seria favorecida pela mudança em direção ao preenchimento do sujeito pronominal e auxiliada pelo prestígio dessa forma.

Quanto às formas de indeterminação em sentenças não-finitas, a autora observa o uso predominante do sujeito nulo nos cinco períodos. O uso de se com infinitivo configurou uma variação estável no sistema, tendo sido encontrado já no primeiro período estudado e apresentando a seguinte distribuição: $23 \%, 11 \%, 16 \%, 10 \%$ e $19 \%$. A autora nota que, desses dados, houve apenas 11 ocorrências de infinitivo com se e argumento interno plural. Observe-se que a pequena amostra restringe-se a exemplos com verbos transitivos diretos, não observando a ocorrência do fenômeno em outros contextos.

De acordo com os resultados encontrados, os contextos mais favorecedores ao uso do se com verbos [-FIN] em todos os períodos é a regência por preposição, em orações completivas nominais, adverbiais e relativas não-canônicas. Atestou-se que, em artigos de opinião, editoriais e crônicas de jornais cariocas do século 19, há uma média de $24 \%$ de presença de se nas infinitivas, enquanto nos jornais do século 20, há uma média de $13 \%$.

No entanto, a pesquisadora observa que a indeterminação não se limita ao uso da $3^{\mathrm{a}}$ pessoa do plural sem pronome expresso ou $3^{\mathrm{a}}$ pessoa do singular associada ao clítico se. No último período da amostragem, ocorre o uso de a gente não correferente com o sujeito da oração principal, introduzindo novas formas de indeterminação do sujeito. Os resultados obtidos em amostras de língua oral mostram um leque maior de estratégias de indeterminação. Entre as formas pronominais plenas, destaca-se o uso de você, a gente, 
eles e nós e o uso reduzidíssimo de se. Segundo a autora, a implementação dessas novas estratégias é lenta, graças à atuação de uma pressão normativa que parece ter sido, pelo menos até os anos 60 , muito bem sucedida na manutenção de traços que há tempos desapareceram da língua falada.

O trabalho elaborado por Duarte (2002), corrobora os resultados de Cavalcante, ampliando o material de análise, que constou de anúncios de jornais brasileiros publicados durante o século XIX. A autora afirma que construções com se para indeterminar o agente nas estruturas [+FIN] são cada vez menos freqüentes no português falado. Preferem-se outras formas pronominais para tal função: você, a gente, eles, categoria vazia (de referência arbitrária por não estar ligada a um SN previamente mencionado).

Foram inicialmente computadas todas as ocorrências de se indeterminador/ apassivador. Numa segunda etapa, foram consideradas apenas as sentenças finitas com verbos transitivos diretos com argumento interno no plural. Nesta pesquisa de caráter sociolingüístico, foram observados os seguintes fatores: (1) Extralingüísticos: procedência (Pernambuco, Bahia, Minas Gerais, Rio de Janeiro, São Paulo, Paraná e Santa Catarina), e período ( de inícios do século XIX a 1840; de 1841 a 1875; de 1876 a 1900); e, (2) Lingüísticos: transitividade verbal, número do argumento interno, concordância entre argumento interno e verbo, posição, estrutura e traço semântico do argumento interno.

A ocorrência do se em estruturas [+FIN] limitou-se a $8 \%$ na amostra de língua espontânea, mostrando que é residual a escolha dessa estratégia de indeterminação. Em contrapartida, nas sentenças [-FIN], constata-se a emergência de se em contextos em que a categoria vazia é recomendada pela gramática normativa. Apesar de não atestar a passagem, a autora propõe uma ordem contrária àquela usada nas sentenças finitas, em que o se passa de apassivador para indeterminador. Em contextos não finitos, o se se insere como indeterminador e vem passando a apassivador:

(14) Para _obter os resultados

(15) Para se obter os resultados

(16) Para se obterem os resultados 
A autora analisou de maneira informal a ocorrência do se nas sentenças nãofinitas. No entanto, ela observa que este ocorre junto a orações reduzidas na seguinte proporção:
De gerúndio - uso do $S E$ em $78 \%$ do total de dados.
De infinitivo - uso do $S E$ em $36 \%$ do total de dados.

Os resultados encontrados corroboram Cavalcante (2002), ao demonstrar que o uso do se é favorecido por contextos regidos de preposição. Nesse trabalho, a autora conclui que existe uma tendência em transformar o se indeterminador em apassivador, pois, da amostra analisada, 5 dos doze infinitivos encontrados apresentavam concordância.

Em trabalho posterior, retomando as construções de indeterminação em anúncios do século XIX, Duarte e Lopes (2002) analisam um corpus formado por cartas de leitores e redatores da Bahia e do Rio de Janeiro, e cartas de leitores de Pernambuco, Minas Gerais, São Paulo e Paraná. A intenção da pesquisa foi aumentar o número de contextos analisados sobre estratégias de indeterminação, visto que o trabalho de Cavalcante privilegiou apenas a análise de editoriais, matérias assinadas e crônicas de jornais cariocas do mesmo período.

As hipóteses lançadas pelas autoras são (1) que as formas se e nós (1 $1^{\mathrm{a}}$. pessoa do plural) concorrem como recursos de indeterminação do agente, recuperando Cavalcante (1999), sendo estratégias em que o referente pode ser, em menor ou maior grau, recuperado no contexto discursivo; (2) que a presença do se em sentenças não-finitas já aparece no século XIX, como atestado por Nunes (1990); (3) a não-concordância com o argumento interno no plural em sentenças finitas com se é fenômeno variável desde o século XVI (Naro,1976 e Nunes, 1990). Observam as autoras que o uso do se constitui uma regra variável, podendo-se dizer que sua ocorrência/ não-ocorrência não altera o significado da sentença na qual ele aparece. Tal hipótese contraria Galves (1987) que afirma que, no PB, a presença do se produz a interpretação não-referencial, diferente da categoria vazia que teria interpretação ambígua. 
Quanto às infinitivas, foram examinadas 272 sentenças com sujeito indeterminado, o que mostrou que a forma preferida é a não-marcação do sujeito. Entretanto, aparecem significativos $27 \%$ de ocorrência do clítico se. Os dados foram divididos em períodos (1808-1840), (1840-1870), (1871-1900), e segundo a procedência dos dados: São Paulo, Minas Gerais, Pernambuco, Bahia, Rio de Janeiro, Paraná.

Observou-se que o segundo período (1841-1870), foi aquele que exibiu a maior ocorrência de $s e, 30 \%$. As autoras assinalam que este mesmo período manifesta a menor concordância entre verbo e argumento interno nas sentenças finitas. São Paulo e Minas Gerais foram as localidades que mais se destacaram no uso do se com verbos [-FIN], com $47 \%$ e $46 \%$ respectivamente.

Obteve-se como único fator relevante a regência da oração [-FIN] por preposição, que, segundo as autoras, explica a larga ocorrência de verbos [-FIN] com se em adverbiais finais e completivas nominais. As construções com se privilegiam os contextos regidos de preposição (71\%), enquanto as construções sem se se distribuem regularmente entre os contextos regidos e não regidos de preposição, com ligeiro favorecimento pelos não regidos.

O último aspecto analisado foi a concordância do verbo [-FIN] com o argumento interno plural. A pequena mostra contrariou a expectativa de que houvesse mais casos de se indeterminador (sem concordância); havendo entre as doze infinitivas com argumento interno no plural analisadas, oito casos de se apassivador, contra quatro de indeterminador. 


\subsection{CONSIDERAÇÕES FINAIS DO CAPÍTULO}

O trabalho inovador de Galves (1987) mostra que, a partir da observação sistemática das diferenças entre o PB e outras línguas românicas e, em particular, o PE, pode-se delinear diferenças gramaticais profundas no que diz respeito ao funcionamento da sentença. Entre os fatores apontados para produzir essa distinção, revela-se a inserção de se em sentenças [-FIN] do PB, que, diferentemente do PE, surge para evitar a vinculação da categoria vazia com o tópico da sentença, proporcionando uma interpretação arbitrária.

Nunes (1990), empreende uma vasta investigação diacrônica das construções com se, encarando o apagamento de se indeterminador em estruturas [+FIN] e a sua inserção em construções [-FIN] como mudanças concomitantes do sistema.

Para além das construções com o se, Cavalcante (2002) verifica que o PB passou a admitir ainda outras formas pronominais de referência indeterminada, como a gente, você, eles e nós nas estruturas com verbos [+FIN] em detrimento do uso do se ou da categoria vazia. Nas construções com verbos [-FIN], revelou-se que a forma predominante ainda é a posição de sujeito vazia, tal qual a gramática normativa prescreve, seguido de longe pelo uso do se, configurando uma variação estável no sistema. Confirmando os resultados de Nunes (1990), a autora encontra indícios do uso do se V-FIN em textos de meados do século XIX. No último período de sua amostra, já se encontram tanto o se indeterminador quanto o apassivador, predominando na amostra sincrônica analisada, a interpretação arbitrária. A amostra se reduziu a exemplos com verbos transitivos diretos, não observando a ocorrência do fenômeno em outros contextos.

Duarte (2002) e Duarte e Lopes (2002) assumem que existe uma tendência em transformar o se indeterminador em apassivador em contextos de verbos [-FIN], embora essa análise tenha sido comprometida pelo número reduzido de dados do corpus.

O quadro abaixo representa, segundo os estudos resenhados neste capítulo, o percurso diacrônico no uso de se: 


\section{PERCURSO DIACRÔNICO DO SE}

SE PASSIVO

\section{SE INDETERMINADOR}

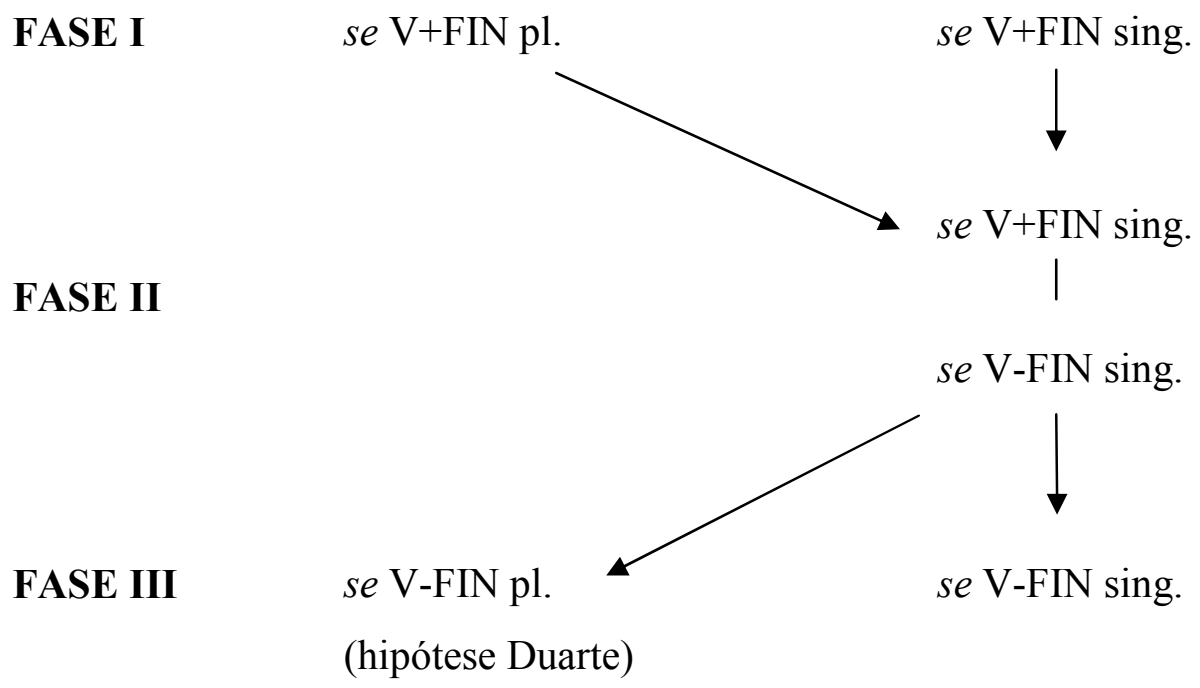

Ao procurar estabelecer contextos [-FIN] em que ocorre a inserção de se, Cavalcante (2002) e Duarte (2002) mostram que as preposições são itens favorecedores desse aparecimento. Considerando, ainda, o tipo de estrutura, observam o aparecimento do se em construções adverbiais finais, completivas nominais e relativas não-canônicas.

Vislumbra-se proceder a uma análise criteriosa sobre o uso de se em estruturas [-FIN] como apassivador ou indeterminador, visto que Duarte (2002) afirma ocorrer, nessas estruturas, uma tendência à produção de se passivo e não indeterminador. Procurar-se-á explicitar também a questão da interpretação da referencialidade nas estruturas $s e V$-FIN, pois existe uma divergência de interpretações nos textos resenhados. Enquanto Galves (1987) considera que, no PB, a presença do se produziria a interpretação não-referencial, diferente da categoria vazia, que teria interpretação ambígua; Duarte \& Lopes (2002) argumentam que a ocorrência/ não-ocorrência do se não alteraria o significado da sentença na qual ele aparece.

No capítulo seguinte, apresentaremos os pressupostos teóricos e metodológicos que nortearam a nossa pesquisa. 
CAPÍTULO II 


\section{PRESSUPOSTOS TEÓRICOS E METODOLÓGICOS}

$\mathrm{Na}$ primeira parte deste capítulo, descrevemos a metodologia utilizada na formação e computação das amostras, bem como fazemos um detalhamento dos procedimentos iniciais da pesquisa: a formação dos corpora, a seleção de dados, os grupos de fatores envolvidos, os testes de produção realizados. Em seguida, apresentamos alguns pontos da Teoria Gerativa que serviram de embasamento para a análise dos resultados.

\section{1. METODOLOGIA}

\subsubsection{FORMAÇÃO DOS CORPORA}

Para a primeira parte do estudo do se V-Fin, foram estabelecidos dois corpora. $\mathrm{O}$ primeiro corpus $(\mathrm{C} 1)$ foi composto por dissertações de mestrado e teses de doutorado de diferentes áreas do conhecimento (humanas, biológicas e exatas) apresentadas à Universidade de São Paulo a partir do ano 2000, provenientes da Biblioteca Digital de Teses e Dissertações da USP - SIBI-NET (Sistema Integrado de Bibliotecas). Com esse sistema digital, pudemos observar todos os casos de introdução do se em sentenças infinitivas constantes nos documentos, sem a perda de nenhum dado, o que poderia acontecer se houvesse apenas a leitura convencional do texto. Assim, esse corpus possibilitou o levantamento de dados em diferentes tipos de contextos lingüísticos.

Abaixo estão arrolados os textos que serviram como fonte de dados para este estudo. Ao final da referência bibliográfica, entre parênteses, está a quantidade de dados encontrados em cada um dos textos: 
1. ARRUDA, S.M. (2001). Entre a inércia e a busca - reflexões sobre a formação em serviço dos professores de física do ensino médio. Tese de Doutorado Faculdade de Educação/USP. (06)

2. BERNI, Cássio de Carvalho (2004). Implementação em Hardwarel Firmware de um sensor virtual utilizando algoritmo de Identificação Nebulosa. Dissertação de Mestrado em Engenharia/USP. (09)

3. RIBEIRO, Adriana Rodrigues (2003). Estudo Anatômico do Plexo Braquial do Macaco Cebus Apella. Dissertação de Mestrado em Medicina Veterinária/USP. (02)

4. GIOVANINNI, Luciano Henrique (2003). Avaliação do Cálcio Sérico Ionizado em Gatos Sadios e em Gatos com Insuficiência Renal Crônica. Dissertação de Mestrado em Medicina Veterinária/ USP. (09)

5. MARTINS, Marcelo Gustavo (2004). A inovação tecnológica na produção de edificios impulsionados pela indústria de materiais e componentes. Dissertação de Mestrado em Engenharia Civil/USP. (12)

6. SOARES, Flávio N.(2003). Prevalência de tentativas e ideação suicida em pessoas com transtornos mentais graves na cidade de São Paulo - Faculdade de Medicina/USP. (09)

7. SILVA, Alexandre A. da (2001). Efeitos da sobrecarga ou restrição crônica de sal na dieta durante a gestação e amamentação em ratas Wistar e sua repercussão sobre a prole. Dissertação de Mestrado - Faculdade de Medicina Veterinária/USP. (04) 
8. RIBEIRO, Maria S.P. (2001). O romper do silêncio: história e memória na trajetória escolar e profissional dos docentes afrodescendentes nas Universidades Públicas do Estado de São Paulo - Dissertação de Mestrado - Faculdade de Educação/USP. (10)

9. GOMES, Marcelo J.S. (2003). Utilização de métodos geofísicos em sambaquis fluviais, região do vale do Ribeira do Iguape - SP/PR - Dissertação de Mestrado- FFLCH/USP. (03)

10. KOBAYASHI, Rika Miyahara (2002). Caracterização da disciplina noções de administração de enfermagem dos cursos de técnico de enfermagem. Dissertação de Mestrado - Faculdade de Enfermagem/USP. (07)

11. PEREZ, Gilberto (2003). Avaliação e Escolha de fornecedores de serviços de Tecnologia da Informação: Um estudo de casos múltiplos - Dissertação de Mestrado - FEA/USP. (37)

12. TOLEDO, Paula Spinha de (2003). Descrição do Comportamento da Cepa de Salmonella Enteritidis PT4 - Dissertação de Mestrado/ Depto. Medicina Veterinária-USP. (05)

13. PESSOTO, U,C.(2001). As políticas de saúde para América Latina e Caribe na Organização Panamericana de Saúde e do Banco Mundial. Dissertação de Mestrado em Integração da América Latina/USP. (07)

A escolha desse corpus se deveu à intuição de que o fenômeno de inserção do se em sentenças não-finitas estava relacionado à estratégia de indeterminação do sujeito e, por tal motivo, o teor científico do texto seria um fator primordial para a produção desse tipo de estrutura. Elencamos grupos de fatores e procedemos à quantificação de dados. 
Outro corpus (C2) foi composto por artigos científicos publicados em revistas especializadas nos últimos vinte anos, dissertações da área de lingüística; anúncios e matérias de jornais e revistas de ampla circulação, publicados a partir de 2000. Nesse segundo corpus, foram recolhidas, ainda, elocuções formais do NURC, redações de alunos, textos impressos de diferentes gêneros, letras de músicas populares. Esse material, apesar de não entrar na contagem estatística, serviu para que pudéssemos proceder a uma observação do comportamento do $s e V-F I N$ em outros contextos que não as dissertações colhidas no sistema SIBI-NET, e comparar as estratégias de inserção elencadas no primeiro corpus com a finalidade de proceder a uma análise criteriosa do uso do se em construções com verbos não-finitos.

1- SILVA, Ana L.Machado (2004). Estratégias Sociointeracionistas de leitura para o gênero romance: Uma aplicação em São Bernardo, de Graciliano Ramos. Dissertação de Mestrado - PUC/SP. (02)

2- IGNÁCIO, Sebastião Expedito (1993). Por exemplo, o ensino da análise sintática. In: Revista Alfa, São Paulo, v.37, p.33-41. (05)

3- CASTILHO, A.T. e PRETI, D. (org.) (1987). A linguagem falada culta na cidade de São Paulo. São Paulo, T.A.Queiroz, v. II: Diálogo entre Dois Informantes. (12)

4- CASTILHO, A.T. e PRETI, D. (org.) 1986. A linguagem falada culta na cidade de São Paulo: materiais para seu estudo. São Paulo, T.A.Queiroz. (02)

5- DE PAULA, Lícia Pupo (2003). Busca de Informação na Internet: Pesquisa Etnográfica com alunos do Ensino Fundamental. Dissertação de Mestrado, USP. (03) 
6- ARAÚJO, Melvina Afra Mendes de (1998). Das ervas medicinais à fitoterapia: encontros e desencontros entre as lógicas biomédica e popular. Dissertação de Mestrado em Antropologia Social - USP. (05)

7- BERGES, Mirela (1999). A projeção da deficiência. Dissertação de Mestrado em Antropologia Social - USP. (03)

8- BRITTO, H.S. (1994). Reduzidas Gerundivas: Teoria do Caso e Inversão Verbo-Sujeito. Dissertação de Mestrado - IEL/Unicamp. (06)

9- RECH, A.L.K. (2003). Em busca do Centro: O significado do centro da cidade de São Paulo para seus habitantes. Dissertação de Mestrado em Geografia Humana - USP. (08)

10- DEZEM, R. (2006). Realidade alterada: o poder da Shindo Renmei. In: Revista História Viva. São Paulo: Ed. Duetto, Dezembro/2005. (03)

11 - SANGALO, I. Abalou. As Super Novas, 2005. (01)

12 - LIVRO DE RECEITAS. Vigilantes do Peso, s/d. (02)

13 - PROPAGANDA POLÍTICA. Campanha Serra/2005. (01)

14 - JORNAL FOLHA DE SÃO PAULO. São Paulo, 20/11/2004. (03)

15 - JORNAL FREGNEWS. São Paulo, 06/11/2004. (02)

16 - REDAÇÕES DE ALUNOS - Ensino Fundamental e Médio 2004-2005. (35) 


\subsubsection{SELEÇÃO DOS DADOS (C1)}

Como assinalamos na introdução deste trabalho, o tratamento realizado com os dados desta pesquisa é quantitativo. Entretanto, não se trata de estudo de variação lingüística, pois não estamos avaliando a oposição zero e se nas construções com verbos [-FIN]. A nossa análise restringe-se aos casos de inserção de se.

Primeiramente, procedemos a um levantamento exaustivo de dados de língua escrita, para fins de análise, dados estes que refletem a inserção do se em estruturas nãofinitas. Trabalhamos com todos os dados coletados em (C1), num total de 120 estruturas colhidas nas 13 dissertações.

Excluímos estruturas que seguiam os seguintes modelos ${ }^{12}$ :

1- SE reflexivo: a exclusão desse elemento se deve ao fato de que ele remete a um referente determinado:

(17) "A identificação da necessidade foi um dos elementos de motivação da Glasser em se lançar a esse desenvolvimento, (...)"

2- SE - inerente: descartamos essa estrutura pelo fato de que o se não é condicionado pelo tipo de estrutura, mas sim pelo tipo de verbo:

12 Como apontado por Nunes (1995), a literatura costuma distinguir sete classes de clíticos anafóricos: se reflexivo (recíproco ou não), se ergativo, se inerente, se índice de espontaneidade, se apassivador, se indeterminador e se médio e, ainda, se ex-ergativo e se quase-inerente, conforme exemplos de seu artigo:

a) se reflexivo:"Depois de jantar se abraçarão reciprocamente" (carta, 1725)

b) se ergativo:"Meu namorado fala alguma coisa, eu não gosto, eu me magôo, eu me machuco" (entrevista)

c) se ex-ergativo:"Como distinguir agora qual o que mais se esforçou na sua ingente construção" (carta, 1920)

d) se inerente:“Aliás, ele se suicidou” (entrevista)

e) se quase-inerente: "Nossa gente de linha e patriota, portou-se valentemente" (telegrama, 1894)

f) se enfático ( índice de espontaneidade):"O dito Gómez hera isemto e que seffosse em paz" (carta, 1555) 
(18) “(...) sobretudo por se tratar do aperfeiçoamento do método (...)”

(19) "A facilidade que ele tinha de se tornar um mestre."

3- SE - em tempos verbais compostos ou locuções verbais: o fato de essas construções apresentarem uma forma finita leva a interpretar o se como pertencendo à construção $s e V+$ Fin e não à construção $s e V$-Fin, nosso objeto do estudo:

(20) "Para garantir a etapa de execução, recomenda-se utilizar as unidades básicas (...)"

(21) “(...) devendo-se garantir a continuidade vertical dos furos (...)”

\subsubsection{GRUPOS DE FATORES}

Computadas todas as ocorrências de $s e V$-FIN, conforme os critérios estabelecidos na primeira seção deste capítulo, procedemos a um levantamento de questões que pudessem estar relacionadas à inserção do $s e$ : i. estrutura argumental dos verbos, ii. presença ou ausência de preposição, iii. tipo de preposição, iv. tipo de elemento que precede a preposição, v. tipo de oração.

\section{i. Estrutura argumental dos verbos}

A relevância desse fator está no fato de que a inserção do se é prescrita pela Gramática Normativa (Bechara 1988, Cunha \& Cintra 1985) com verbos biargumentais, favorecendo a leitura passiva. Entretanto, os trabalhos de Naro (1976) e de Nunes (1990) apontaram a tendência à perda da leitura passiva em favor da leitura ativa, graças à perda da concordância verbal. Naro chega a postular que as estruturas indeterminadas de se $\mathrm{V}+$ Fin são mais recentes do que as estruturas passivas. Por este fator, buscamos observar se a inserção do se se dá apenas em estruturas biargumentais que retratam uma 
construção passiva ou se, da mesma maneira que ocorreu para as estruturas se $\mathrm{V}+\mathrm{Fin}$, já atinge verbos monoargumentais.

\section{ii. Presença ou ausência de preposição}

Tendo em vista que verbos não-finitos podem ou não ser precedidos de preposição, retomamos a hipótese de Cavalcante (2002), Duarte (2002) e Duarte e Lopes (2002) de que o se em construções com verbos [-FIN] emerge na presença de uma preposição.

\section{iii. Tipo de preposição}

Este grupo de fator foi criado para observar qual a preposição mais recorrente na estrutura seV-FIN. Considerando que algumas preposições podem assumir a função de complementizador, constituindo uma fronteira sentencial (barreira), conforme propõe Rizzi (1995), postularemos a hipótese de que a emergência do se ocorreria na sentença em que a preposição teria essa função, o que impediria uma leitura referencial, acionando uma leitura arbitrária, marcada pelo se.

\section{iv. Tipo de elemento que precede a preposição}

Os trabalhos realizados ${ }^{13}$ com a estrutura seV-Fin contemplam a construção adjetival, como é o caso da expressão é difícil de. A análise da categoria que precede a preposição poderá mostrar se essa estrutura se filia apenas à classe adjetival ou se há outras classes, inclusive um elemento nulo, que possam preceder a preposição.

\section{v. Tipo de oração}

Esse grupo foi criado com a intenção de verificar se existe um tipo de oração recorrente no qual se insere o se.

\footnotetext{
${ }^{13}$ Destacamos aqui os trabalhos de Galves (2001) e Cavalcante (2002).
} 


\subsubsection{TESTES DE PRODUÇÃO}

Numa segunda etapa do trabalho, foram realizados testes de produção com 56 alunos (doravante, informantes) do $3^{\circ}$. Ano de Graduação em Letras da Universidade de São Paulo, no curso de Filologia da Língua Portuguesa ${ }^{14}$. A escolha deste público se deveu à intenção de trabalhar com falantes cultos da língua portuguesa e de tornar isonômica a amostra, visto que os dados colhidos na primeira parte deste trabalho, conforme explicitamos na parte anterior, provêm de dissertações de mestrado e teses de doutorado de diferentes áreas do saber.

O teste de produção nos pareceu uma ferramenta bastante interessante na análise de dados porque, segundo Tarallo (2001), "consiste em mecanismos que levam o informante a construir a variável". Ao preencher o teste, o informante opta por uma ou outra variante. Como exemplificação, numa sentença como $A$ chance de .... é mínima, o informante pode escolher preencher a lacuna com um verbo [-FIN] precedido de zero, se ou qualquer outro índice referencial. Assim, o informante usa a forma padrão ou nãopadrão.

Com esses testes, pretendemos observar as estratégias utilizadas na complementação das sentenças. Para isso, pedimos para que os alunos completassem as lacunas com uma oração. Como propusemos um input ${ }^{15}$, o informante ficou, por um lado preso à estrutura posta a sua disposição, ao tópico; por outro, solto na escolha semântica.

Os dados coletados poderiam confirmar os resultados encontrados na primeira parte do trabalho. Nesse caso, poderia ocorrer a complementação com oração [-FIN] ou [+FIN], com ou sem preposição, proporcionando ou não a entrada da partícula se. Abaixo estão as 14 sentenças do teste, as quais descreveremos detalhadamente a seguir:

\footnotetext{
${ }^{14} \mathrm{O}$ curso de Filologia da Língua Portuguesa é ministrado no $6^{\circ}$ semestre. Anteriormente a ele, os alunos passaram pelos cursos de Variação Lingüística, Morfologia e Sintaxe, pelo menos. Vale ainda dizer que se espera do aluno de Letras conhecimentos metalingüísticos maiores do que os encontrados em alunos de outras áreas.

${ }^{15} \mathrm{O}$ termo input, como usado aqui, refere-se à estratégia de delimitação de produção, seja ela em termos semânticos ou sintáticos.
} 
S1- Iniciou-se o trabalho...

S2- Antes de iniciar o trabalho...

S3- Ao se falar de filme brasileiro...

S4- A probabilidade... é uma em um milhão.

S5- Depois de chegar em casa...

S6- É impossível de...

S7- Abriram-se as portas...

S8- Antes de se iniciar a discussão...

S9- A chance de .... é mínima.

S10-Ao falar de literatura...

S11-Depois de se chegar no trabalho...

S12- É difícil...

S13- A dificuldade... é avaliada pelos economistas.

S14- Fechou-se a porta...

Para tornar o teste o mais natural possível, usamos a técnica do distrator; isto é, os exercícios S1, S7 e S14 não avaliam a produção da variante, apenas fazem com que o analisando não perceba o que está sendo avaliado. Os distratores usados, no entanto, não correspondem a qualquer tipo de estrutura; neles há uma estrutura $[+\mathrm{FIN}]$ com a presença do se, configurando casos típicos de passiva sintética; S1 e S14 com argumento interno no singular, e S7 com argumento no plural, concordando com o verbo no plural.

As sentenças foram divididas em dois grupos, pois previa-se duas diferentes abordagens, de acordo com o input dado. O primeiro grupo foi formado de sentenças encaixadas adverbiais, cabendo ao informante a construção de uma oração matriz. As sentenças que previam esta abordagem foram S2, S3, S5, S8, S10, S11. Nestes casos, não objetivávamos observar a presença ou a ausência de $s e$, mas sim a referencialidade que o informante atribuiria à matriz, tendo em vista que algumas encaixadas apresentavam o se e outras não.

Com base em Galves (2001), partimos da hipótese de que a presença do se na encaixada ativaria um sujeito não-determinado na matriz. Por sua vez, a ausência do se detonaria um sujeito determinado. Extraímos daí a seguinte hipótese implicacional: 


\section{Hipótese implicacional 1}

Se "se", então [-DET]

Se Ø, então [+DET]

Criamos três pares de sentenças encaixadas para proceder a comparação (S2-S8, S3-S10, S5-S11). Em S2 e S8, procuramos criar um paralelismo entre tipo de oração (temporal); o tipo de verbo (biargumental); e, o tipo de preposição (de). Assim, poderíamos observar se o usuário preencheria com uma estrutura determinada ou indeterminada.

S2- Antes de _ iniciar o trabalho...

S8- Antes de se iniciar a discussão...

Em S3 e S10, continuamos com as orações temporais, mas alteramos o tipo de verbo $^{16}$, a preposição $(a)$, e mantivemos a alternância presença/ ausência de $s e$.

S3- Ao se falar de filme brasileiro...

S10- Ao _ falar de literatura...

Entre S5 e S11, privilegiamos a distribuição do se junto a verbos inacusativos, a fim de verificar se esse tipo de verbo alteraria a referencialidade da matriz.

S5- Depois de _ chegar em casa...

S11- Depois de se chegar no trabalho...

Assim, nos três pares criados, o informante deveria preencher com uma oração matriz. Esta, por sua vez, traria um sujeito determinado ou indeterminado.

\footnotetext{
${ }^{16} \mathrm{O}$ verbo falar, como empregado na sentença, foi considerado biargumental.
} 
Já o segundo grupo de sentenças consistia de uma oração matriz. $\mathrm{O}$ aluno deveria completá-la com uma encaixada. Esperávamos que o aluno construísse a estrutura [-FIN], a fim de verificarmos se esta estrutura acolheria ou não o se. Em três orações, o informante deveria complementar um nome (S4, S9, S13):

S4- A probabilidade... é uma em um milhão.

S9- A chance de... é mínima.

S13- A dificuldade... é avaliada pelos economistas.

E, em duas delas, um adjetivo (S6, S12).

S6- É impossível de...

S12- É difícil...

Nossos objetivos eram observar se:

1- o aluno, ao construir uma oração [-FIN], incluiria uma preposição;

2- ao incluir uma preposição, o aluno ativaria o uso do se.

Decorreria daí a segunda hipótese implicacional:

\section{Hipótese implicacional 2}

Se [prep], então se

Se Ø, então Ø.

Nas sentenças completivas de nome, $\mathrm{S} 4$ e S13, foram dados os nomes, mas não foi dada a preposição com a intenção de verificar se haveria ou não este preenchimento e, por conseguinte, a ativação ou não do uso de se. Já em S9, a intenção foi verificar se a preposição promovia o uso do se.

Produzimos o mesmo paralelismo nas estruturas adjetivas S6 e S12. A primeira com preposição e, a segunda, deixando a cargo do aluno o preenchimento. 


\subsection{PRESSUPOSTOS TEÓRICOS}

\subsubsection{CATEGORIA VAZIA PRO E TEORIA DA LIGAÇÃO}

Nesta seção, iremos resgatar um pouco da teorização sobre as categorias vazias, mais especificamente da teoria de ligação e do controle. A Teoria de Ligação estabelece a distribuição de índices referenciais entre os diversos tipos de DPs. Mioto (2005) assim resume os três tipos de DPs que as línguas naturais exibem:

Anáfora

- deve ter um antecedente, isto é, um elemento com o mesmo índice;

- este antecedente deve c-comandar ${ }^{17}$ a anáfora;

- este antecedente deve estar dentro de um certo domínio, chamado “domínio de vinculação", que parece depender da presença de um sujeito e de mais alguma coisa para ser corretamente definido.

Pronome

- pode apresentar um antecedente, mas não é necessária a presença de um;

$\bullet$

- se houver antecedente, ele não pode c-comandar o pronome dentro de um certo domínio, mas pode c-comandá-lo fora deste domínio;

- aparentemente este "domínio de vinculação" é o mesmo que conta para a anáfora, dada a distribuição complementar que existe entre pronomes e anáforas.

\footnotetext{
${ }^{17}$ Formulação de c-comando: $\alpha$ c-comanda $\beta$ se e somente se:

(i) $\alpha$ não domina $\beta$ nem $\beta$ domina $\alpha$;

(ii) cada nódulo ramificante $\gamma$ que domina $\alpha$ também domina $\beta$.
} 
Expressão-R

- não requer antecedente, porque tem autonomia referencial;

- $\quad$ se houver antecedente, ele não pode c-comandar a expressão-R em nenhum domínio.

Assim, abaixo são apresentadas as possibilidades que os DPs têm de serem coreferentes:

\section{PRINCÍPIO DE VINCULAÇÃO}

A: uma anáfora tem de estar vinculada em seu domínio de vinculação;

B: um pronome tem de estar livre em seu domínio de vinculação;

C: uma expressão-R tem de estar livre.

Da mesma forma que os DPs realizados foneticamente apresentam propriedades de ligação, as categorias vazias também são passíveis da mesma categorização. Chomsky (1982) propõe um inventário das categorias vazias:

\begin{tabular}{|lll|}
\hline \multicolumn{1}{|c|}{ TIPOLOGIA DOS DPS LEXICAIS/ VAZIOS } & \\
TIPO & PLENO & VAZIO \\
& & \\
{$[$ +anafórico, -pronominal $]$} & anáforas & vestígio $(v)$ \\
{$[$-anafórico,, pronominal $]$} & pronomes & pro \\
{$[$-anafórico,, pronominal $]$} & expressões-R & variável $($ var $)$ \\
{$[$ +anafórico,, pronominal $]$} & --------- & PRO \\
\hline
\end{tabular}

O Princípio da Projeção Estendido (EPP) estabelece que todo verbo, sem exceção, projeta a posição de sujeito. Assim, inclusive o V-FIN tem uma posição reservada para o sujeito. No caso em questão, o PRO figura como sujeito vazio da oração infinitiva, 
encaixada à matriz finita. PRO pode se comportar como uma anáfora (22), quando possui um antecedente; ou como um pronominal (23), quando tem referência arbitrária.

(22) Eu quero PRO comer camarão.

(23) Eu me pergunto como [ PRO enriquecer neste país].

A Teoria de Ligação não comporta a atribuição de índices referenciais a PRO, pois é incoerente que PRO seja, ao mesmo tempo [+anafórico] e [+pronominal], tendo de obedecer simultaneamente aos princípios A e B dessa teoria. A Teoria de Controle foi criada com a intenção de explicar a aquisição de índice referencial por PRO.

\subsubsection{A TEORIA DE CONTROLE}

Construções com PRO possuem propriedades específicas de coindexação, estando a noção de controle relacionada a fatores, como o tipo de verbo matriz e o tipo de construção em que se insere a infinitiva com o sujeito PRO.

Segundo a regra de controle proposta por Jackendoff (1972), as estruturas de controle apresentam um controlador e um elemento controlado. Em princípio, o controlador é o DP da oração matriz que estabelece relação de correferencialidade com o sujeito do verbo não-finito da encaixada (PRO). Dois fatores interagem para explicar o controle de PRO: o princípio de c-comando e a proximidade.

De acordo com os princípios da Teoria de Controle de Chomsky (1986a), PRO deve ser controlado por um antecedente que o c-comande, isto é, receba o mesmo índice referencial do antecedente.

As condições de controle são as seguintes: 
(i) havendo um controlador potencial, PRO estabelece correferência com esse controlador, obedecendo às seguintes condições:

- primeiramente, com o controlador imediatamente superior ou mais próximo;

- se o verbo da oração matriz é um verbo $[+\mathrm{CS}]^{18}$, o controlador é potencialmente o sujeito dessa oração,

- se o verbo da oração matriz é $[+\mathrm{COD}]^{19}$, o controlador é obrigatoriamente o objeto direto dessa oração,

- se o verbo da oração matriz é $[+\mathrm{COI}]^{20}$, o controlador é obrigatoriamente o objeto indireto dessa oração;

- nas estruturas ambíguas, de controle tanto pelo sujeito como pelo objeto, o contexto determina o controlador;

(ii) $\mathrm{Na}$ ausência de um controlador potencial, a referência deve ser livre, e, portanto, a interpretação é arbitrária.

Pela Teoria de Controle, PRO é caracterizado como um elemento controlado ou arbitrário, coindexado a um antecedente, mas não $\operatorname{ligado}^{21}$. Souza (2002) discute a questão da identidade referencial de PRO com um eventual antecedente, bem como de PRO nos contextos em que não há um antecedente.

(24) $[\mathrm{O} \text { professor }]_{\mathrm{i}}$ permitiu a[os alunos $]_{\mathrm{j}}\left[\mathrm{PRO}_{\mathrm{j}}\right.$ sair mais cedo $]$.

(25) João pediu a Paulo para [PRO ${ }_{i j}$ sair].

(26) [PRO lançar a bomba atômica] seria uma catástrofe para o mundo inteiro.

(Raposo, apud Souza 2002)

\footnotetext{
${ }^{18}$ Controle pelo sujeito.

${ }^{19}$ Controle pelo objeto direto.

${ }^{20}$ Controle pelo objeto indireto.

${ }^{21}$ Chomsky (apud Souza 2002) estabelece a diferença entre coindexação e ligação. A primeira define-se em termos de atribuição de índices referenciais, enquanto a segunda, pelos princípios de ligação, considera não só o regente e a categoria de regência, mas também a natureza do SD em questão.
} 
Nos dois primeiros exemplos PRO é controlado, estabelecendo correferência com um antecedente, assim como acontece com os anafóricos, com a diferença, no entanto, de que em estruturas com o sujeito PRO, diz-se que ele é controlado por um DP da oração superior. Segundo Raposo (apud Souza 1998), o contexto pragmático, além do contexto frásico, teria influência na determinação do antecedente de PRO. Em certos contextos, como em (25), PRO pode tomar tanto o sujeito como o objeto da oração mais alta como antecedente, em outros contextos ainda, (26), PRO não tem um referente com o qual se coindexa, admitindo-se uma interpretação genérica ou arbitrária.

\subsubsection{PRO ARBITRÁRIO}

As propriedades de controle de PRO sem um antecedente na sentença são diferentes daquelas em que há um antecedente. Segundo Raposo e Britto (apud Souza 1998), quando PRO não possui um antecedente que o c-comande, deve receber uma interpretação arbitrária, mediante a qual passa a incorporar os traços de um pronome indefinido genérico.

Britto propõe Caso Nulo para o PRO das gerundivas, com base em evidências empíricas de que, no PB, o PRO pode muitas vezes ser lexicalizado. Assim, certos pronomes no PB funcionam como lexicalizações do sujeito PRO, recebendo, como esse um Caso Nulo. A evidência reside no fato que, no PB, tanto pode ocorrer o sujeito PRO da infinitiva, como o indefinido alguém. PRO também pode ser substituído pelos pronomes vocêl a gente, denotando uma interpretação também indefinida. Você, eu, a gente são lexicalizações do elemento arbitrário PRO com interpretação genérica e, segundo Souza (op.cit.), seria adequado assumir PRO lexicalizado para o sujeito das infinitivas também.

Chomsky (1986b) propõe que PRO deve possuir um Caso inerente em sua matriz gramatical, com base no fato de que as categorias $[+\mathrm{N}]$, como N, A e P, são atribuidoras de Caso inerente. O Caso inerente é o caso do Genitivo e Oblíquo, distinto do Caso estrutural, do nominativo e do acusativo, sendo atribuído por N, A e P ao complemento 
selecionado por essas categorias, paralelamente à atribuição da função temática. Considera-se que PRO recebe seu papel temático do predicador da oração encaixada que o contém.

A questão de atribuição de Caso a PRO é revista por Chomsky e Lasnik (1991) ao proporem que o Caso é atribuído ao sujeito, não sob condições de regência, mas sob concordância. Assim, resgatamos um pouco da teoria de Caso e verificamos que, ao contrário dos sujeitos das orações finitas que devem conter o traço de Caso Nominativo, PRO possui um Caso Nulo. Pelos princípios de regência, PRO não poderia receber um caso, se considerado não-regido. Entretanto, evidências empíricas mostram que o sujeito de orações infinitivas assume identidade fonética, podendo alternar com PRO. Surge, daí, a idéia de Caso Nulo em sentenças de Tempo [-finito],contexto em que Agr deve atribuir Caso Nulo para a categoria vazia PRO situada em Spec de IP ou Agr.

Chomsky e Lasnik (1991) sugerem que PRO é sempre controlado por um argumento (explícito ou não), isto é, pode-se interpretar PRO arbitrário controlado por um argumento implícito ou contextual.

(27) É proibido (a todos ${ }_{i}$ ) [PRO fumar .

Considerando com Souza e Britto (op.cit) que o PRO possa, em alguns contextos, ser lexicalizado, hipotetizamos que o se seja uma lexicalização de PRO, da mesma maneira que outros pronomes indefinidos genéricos todos/alguém. Assim, consideramos que o se das infinitivas também possa receber Caso Nulo, como apontado por Chomsky e Lasnik (op.cit), situando-se em Spec de IP ou Agr.

Objetivamos, nesse capítulo, resgatar um pouco dos estudos sobre a categoria vazia PRO, a teoria de ligação e a de controle a fim de situarmos o fenômeno em estudo dentro das discussões elaboradas no modelo gerativista. Passaremos agora às discussões feitas por Radford (2004) sobre a distinção entre preposições e complementizadores no inglês. 


\subsubsection{COMPLEMENTIZADORES}

Radford (2004) distingue complementizadores (C) de outras categorias do inglês, como algumas preposições; e define-os como uma classe funcional usada para introduzir orações completivas:

(a) I think [that you may be right]

(b) I doubt [if you can help me]

(c) I'm anxious [for you to receive the best treatment possible]

Nos exemplos usados pelo autor, cada uma das orações entre parênteses em (28) é uma oração completiva e sua função é a de complemento da palavra imediatamente anterior (think, doubt, anxious); as palavras em itálico que introduzem cada oração são conhecidas como complementizadores - que na gramática tradicional são chamadas de conjunções subordinativas.

Procuramos reproduzir toda a argumentação utilizada pelo autor para descrever complementizadores, a fim de que toda a reflexão seja capturada e sirva de base para nossa argumentação. Assim, Radford esclarece que complementizadores determinam ${ }^{22}$ finitude pelo fato de serem intrinsecamente finitos ou não-finitos. Mais especificamente no inglês, os complementizadores that e if são "inerentemente" finitos por só poderem introduzir orações finitas, enquanto for é "inerentemente" infinito por só introduzir oração infinitiva.
(a) * I think [that you to be right]
(b) * I doubt [if you to help me]
(c) * I'm anxious [for you should receive the best treatment possible]

\footnotetext{
${ }^{22}$ No inglês, encode.
} 
Os exemplos (29a,b) acima são agramaticais porque that $\mathrm{e}$ if são complementizadores finitos e não podem ser usados com verbos infinitivos, (29c) é agramatical porque for é complementizador infinito e não pode introduzir uma oração finita contendo um verbo auxiliar no passado como should.

Radford expõe que Complementizadores, em estruturas como (28), têm três funções gramaticais. A primeira é marcar a oração introduzida como uma encaixada; a segunda, indicar a finitude da oração; e, a terceira, marcar força da oração introduzida, sendo que, tipicamente if introduz uma oração interrogativa, that introduz oração declarativa e for introduz oração hipotética.

No entanto, a questão é for/that/if devem ser encarados como uma nova categoria ou como tradicionalmente se faz- for pode ser encarado como preposição, that, um determinante e if um advérbio? Segundo suas pesquisas, existem diferenças significantes entre complementizadores e outras palavras similares, o que faz com que não se possa assumir a categorização tradicional. Por exemplo, uma diferença entre o complementizador e a preposição for é que a preposição apresenta conteúdo semântico substancial e, em alguns, mas não em todos, podem ser intensificados por "straight/ right'.

(a) He headed straight/right for the pub [for = preposition]

(b)The dog went straight/right for her throat [for = preposition]

(c)*He was anxious straight/right for nobody to leave [for $=$ complementiser]

(d)*It is vital straight/right for there to be peace [for = complementiser]

O autor mostra que, além da questão posta acima, a preposição e o complemento for diferem em seu comportamento sintático. Por exemplo, uma oração introduzida pelo complementizador for pode ser o sujeito de uma expressão como would cause chaos, enquanto uma preposição for não pode.

(a) For him to resign would cause chaos [ $=$ for-clause]

(b)* For him would cause chaos [=for-phrase] 
O que faz a análise unificada não ser plausível é que as preposições no inglês não são geralmente seguidas por um complemento infinitivo, como abaixo:

(a) *She was surprised at [there to be nobody to meet her]

(b) *I'm not sure about [you to be there]

(c) * I have decided against [us to go there]

O único complemento verbal que a preposição admite no inglês são estruturas gerundivas. Vejamos o exemplo:

I'm against capitulating/*capitulate.

Outra diferença entre o complementizador e a preposição for é que o nome, pronome ou expressão interrogativa Who? What? Which one? podem se movimentar para o início da sentença com ou sem o for caso for seja uma preposição, mas não se for um complementizador. Por exemplo, em (34), for funciona como uma preposição e Senator Megabucks funciona como seu complemento. Então, se for trocada essa expressão por Which Senator?, a expressão wh- pode ser alçada com ou sem a preposição (sem a preposição, na linguagem informal; e, com a preposição, na linguagem formal). Da seguinte maneira:

(a) I will vote for Senator Megabucks in the primaries

(b) Which senator will you vote for in the primaries? [=informal style]

(c) For which senator will you vote in the primaries? [=formal style]

No entanto, em (35a), a expressão em itálico não é complemento do complementizador for ( o complemento de for em (35a) é a oração infinitiva Senator Megabucks to keep his cool), precisamente é o sujeito da expressão to keep his cool; por essa razão, se trocarmos Senator Megabucks por uma expressão interrogativa wh-, a expressão não pode se movimentar para o início da sentença, com ou sem o for. 
(35)

(a) They were anxious for Senator Megabucks to keep his cool

(b)*Which senator were they anxious for to keep his cool?

(c)*For which senator were they anxious to keep his cool?

E ainda, quando for funciona como complementizador, a oração encaixada inteira pode ser substituída por uma oração introduzida por outro complementizador; por exemplo, a oração encaixada em itálico em (36a) pode ser trocada pela oração com that em (36b).

(a) Is it really necessary for there to be a showdown?

(b) Is it really necessary that there (should) be a showdown?

Em contraposição, a expressão em itálico em (37a) não pode ser trocada por uma oração iniciada com that.

(a) We are heading for a general strike

(b) *We are heading that there (will) be a general strike

Portanto, para Radford, existem evidências de que a preposição for e o complementizador for são categorias distintas. São itens lexicais pertencentes a categorias diferentes.

Em seguida, o autor revê a questão de que o complementizador that pode ser analisado como um determinante.

(a) I refuse to believe that [rumour]

(b) I refuse to believe that [Randy Rabbit runs Benny's Bunny Bar] 
That tem o status de determinante em sentenças como (38a), assim, supõe-se que that introduz a oração Randy Rabbit runs Benny's Bunny Bar em sentenças como (38b) funcionando como um determinante "pré-oracional" 23 . No entanto, para o autor, existe uma evidência contra essa análise e trata-se de uma evidência de natureza fonológica. No uso como complementizador, that apresenta uma forma reduzida (ðət), enquanto no uso como determinante, that invariavelmente não apresenta redução (ðæt). As diferenças fonológicas mostram que se tratam de dois itens lexicais diferentes.

Mais além, that em seu uso como determinante pode ser substituído por outro determinante, como this ou the.

(a) Nobody else knows about that incident/ this incident/ the incident (=determiner that)

(b) I'm sure that it's true/* this it's true/ *the it's true (=complementiser that).

De maneira parecida, o determinante that pode ser usado como um "pronominal determiner", isto é, sem complemento; enquanto o complementizador não pode.

(a) Nobody can blame you for that mistake (prenominal determiner)

(b) Nobody can blame you for that (pronominal determiner)

(a) I'm sure that you are right (preclausal complementiser)

(b) * I'm sure that (pronominal complementiser)

A diferença fonológica e sintática entre os dois exemplos mostra que existem diferenças entre o elemento que introduz orações-complemento- pertencentes à categoria complementizadores (C) - e o determinante (D), que modifica expressões nominais.

$\mathrm{O}$ terceiro item sugerido como complementizador é o interrogativo if. No entanto, à primeira vista, parece que existe um paralelismo entre if e wh-adverbs (advérbios

\footnotetext{
${ }^{23}$ No inglês, preclausal determiner, isto é, um determinante introduzindo uma oração.
} 
interrogativos) como when/where/whether, por eles ocuparem a mesma posição na sentença, como:

(a) I don't know [where/when/whether/ if he will go]

Assim, o autor esclarece que somos tentados a analisar if como um advérbio interrogativo. No entanto, existe uma série de razões para rejeitar esta possibilidade. If difere de advérbios interrogativos não apenas em sua forma, mas também numa série de posições sintáticas que pode ocupar. Por exemplo, wh-adverbs podem ocorrer em orações finitas e infinitivas, enquanto o complementizador if restringe-se a introduzir orações finitas.

(a) I wonder [when/where/whether/if I should go] [=finite clause]

(b) I wonder [when/where/whether/* if to go] [=infinitive clause]

Além disso, if é diferente de wh-adverbs interrogativos (mas similar a outros complementizadores), pois não pode ser usado para introduzir uma oração que serve como complemento de uma preposição.

(a) I'm not certain about [whether/when/where/*if he'll go]

(b) * I'm concerned over [if taxes are going to be increased]

(c) * I'm puzzled at [that he shoulk have resigned]

(d) * I'm not very keen on [for you to go there]

Finalmente, enquanto o wh-adverb pode ser coordenado com o advérbio not, if não aceita tal coordenação. 
(a) I don't know [whether or not he'll turn up]

(b) * I don't know [if or not he'll turn up]

Por razões como as apresentadas, o autor acha mais apropriado categorizar if como um complementizador interrogativo, e whether/where/when como advérbios interrogativos.

Dessa maneira, a discussão mostra a necessidade da categoria $\mathrm{C}$ para designar itens como if/that/for que têm a função, em determinados contextos, de introduzir tipos específicos de orações finitas e não-finitas. O questionamento produzido nessa seção nos guiará na classificação de alguns itens introdutores de orações não-finitas no PB.

\subsubsection{O DESMEMBRAMENTO DA CATEGORIA CP (RIZZI 1995)}

Em trabalho de 1995, Rizzi desmembra a categoria CP, que passa a abrigar as categorias Tópico e $\mathrm{Foco}^{24}$ entre as especificações fixas Força e Finitude. Da seguinte maneira:

$$
\text { CP [ FORÇA... tópico... foco... tópico... FINITUDE] IP }
$$

$\mathrm{Na}$ posição mais alta do $\mathrm{CP}$, Força ilocucionária engloba complementizadores capazes de informar se a sentença é exclamativa, interrogativa, declarativa ou relativa. $\mathrm{O}$ verbo da oração matriz seleciona o tipo de oração encaixada, por meio do valor [ $\pm \mathrm{WH}]$. Se o verbo selecionar um COMP marcado com traço [+WH], gera uma frase interrogativa. Se o verbo selecionar um COMP com traço [-WH], gera uma frase declarativa, como pode ser visto nas sentenças do italiano:

\footnotetext{
${ }^{24}$ Segundo Rizzi (1995), Tópico e Foco são projeções nem sempre ativadas. TopP é a articulação de tópico-comentário e FocP é a articulação de foco-pressuposição. Tópico, por ser uma projeção recursiva, pode aparecer antes ou depois de Foco. Por fugir à alçada deste trabalho, não discutiremos aprofundadamente essas projeções.
} 
(46)

(a) Mi domando $[s e[+\mathrm{WH}]$ Giovanni viene.

(b) Disse $[$ che $[-\mathrm{WH}]$ Giovanni viene.

Rizzi (1995) mostra que além de articular a oração matriz à encaixada, determinando sua especificação em termos dos traços $[ \pm \mathrm{WH}]$, o CP também tem a função de articular traço de finitude do CP com o verbo da encaixada. A categoria Finitude relaciona C ao sistema IP, especificando tempo. Assim, em (47a), um COMP com realização fonética che determina uma flexão [+FIN]; enquanto, em (47b), um COMP nucleado pela preposição di, no italiano, determina uma flexão [-FIN]:

(a) Penso [CP[C'] [C che] [IP _ troverò la risposta $]$.

(b) Penso [CP[C'] [C di] [IP _ trovare la risposta]].

Che determina traços [-WH] e [+FIN], enquanto di determina traços $[-\mathrm{WH}] \mathrm{e}$ [-FIN].

Sintetizamos no esquema:

ITALIANO

\begin{tabular}{|cc|}
\hline$[+\mathrm{WH}]$ & {$[+\mathrm{FIN}]$} \\
se & \\
{$[-\mathrm{WH}]$} & {$[+\mathrm{FIN}]$} \\
che & \\
{$[-\mathrm{WH}]$} & {$[-\mathrm{FIN}]$} \\
$d i$ & \\
\hline
\end{tabular}


No inglês, if determina traços [+WH] e [+FIN], enquanto Ø e that determinam traços [-WH] e [+FIN]:

He wonders [if he will arrive late].

He said [Ø he will arrive late].

He said [that he will arrive late].

Em (50), to e for determinam [-WH] e [-FIN]:

This knife is only [to cut bread].

This knife is only [for cutting bread].

Podemos sistematizar assim:

\section{INGLÊS}

\begin{tabular}{|cc|}
\hline$[+\mathrm{WH}]$ & {$[+\mathrm{FIN}]$} \\
if & {$[+\mathrm{FIN}]$} \\
& \\
that $/ \varnothing$ & {$[-\mathrm{WH}]$} \\
{$[-\mathrm{WH}]$} & \\
tolfor & \\
\hline
\end{tabular}


No $\mathrm{PB}$, se determina traços $[+\mathrm{WH}]$ e $[+\mathrm{FIN}]$. Os traços [-WH] e [+FIN] são conseguidos com que:

(a) Perguntei [se o João vem].

(b) Disse [que o João vem].

Em (52), Ø determina traços [-WH] e [-FIN]:

João disse [Ø gostar de computadores].

A sistematização para o PB:

\section{PORTUGUÊS BRASILEIRO}

\begin{tabular}{|cc|}
\hline$[+\mathrm{WH}]$ & {$[+\mathrm{FIN}]$} \\
se & {$[+\mathrm{FIN}]$} \\
{$[-\mathrm{WH}]$} & \\
que/ $\varnothing^{25}$ & \\
{$[-\mathrm{WH}]$} & \\
$\varnothing$ & \\
\hline
\end{tabular}

Nessa seção, viu-se que, no $\mathrm{PB}$, a preposição não tem função de núcleo de $\mathrm{CP}$ quando este é subcategorizado pelo verbo. Na próxima seção, trataremos da possibilidade de o núcleo $\mathrm{C}$ abrigar uma preposição em contextos de não subcategorização por um verbo.

\footnotetext{
${ }^{25}$ Ainda existe a possibilidade de $\varnothing$, em algumas variedades lingüísticas, apresentar traços [-WH], [+FIN], como no exemplo:

Imaginou Ø tivessem trazido as encomendas.
} 


\subsubsection{PREPOSIÇÕES LEXICAIS E FUNCIONAIS NA SUBORDINAÇÃO SENTENCIAL}

Ao estudarem estruturas de complementação no PB, Mioto \& Kato (2002) encararam a preposição como um núcleo ao qual sentenças infinitivas se subordinam. "As sentenças têm que ser licenciadas por um núcleo externo sob regência ou têm que ser adjuntas a um constituinte (não-nuclear). Em especial, uma sentença infinitiva se subordina diretamente apenas a dois núcleos, que são o verbo e a preposição; uma sentença infinitiva, desconsiderando as que são sujeito, só pode se subordinar a um nome ou adjetivo por meio de uma preposição."

A subordinação à preposição, segundo os autores, não ocorre apenas em orações completivas de verbos, nomes ou adjetivos, ocorre também com orações convencionalmente chamadas de adverbiais. Nesse caso, a sentença é um complemento de uma preposição e o constituinte preposicional como um todo é o adjunto.

Baseando-se em estudos anteriores ${ }^{26}$, os autores concordam que o complementizador que ocupa a posição de núcleo de $\mathrm{CP}$ especifica o traço de finitude do verbo da encaixada. Um complementizador com realização fonética na posição de COMP determina uma flexão finita, ou seja, com especificação de tempo. Um complementizador vazio, sem realização fonética, determina uma flexão não-finita.

Ao diferenciarem preposições lexicais e funcionais, os autores definem que, no $\mathrm{PB}$, algumas preposições lexicais selecionam diretamente um $\mathrm{CP}$ que pode ter núcleo nulo (53) ou preenchido por que (54).

(53) $\operatorname{por}$ [ cP ser no escuro] demonstra que a imagem não foi feita para ser vista por outras pessoas

(54) ele é melhor por [ср que... dá mais espiga]

(Mioto \& Kato 2002:394)

\footnotetext{
${ }^{26}$ Citamos aqui Rizzi (1995).
} 
Assim, algumas preposições, que na gramática tradicional eram encaradas como conjunções, passam a ser analisadas como \{preposições $+\mathrm{C}$ \}, selecionando um $\mathrm{C}$ como complemento. Vejamos (55):

(a) Porque eles têm uma briga eles se preparam

(b) Por eles terem uma briga eles se preparam

No par de exemplos acima, a relação de causa fica mantida na presença ou ausência de que, o que evidencia não existir "conjunções causais ou finais", mas, sim, preposições causais e finais que selecionam uma sentença como complemento.

Quanto às preposições funcionais (de, a, para, com e em), Mioto \& Kato (op.cit) afirmam que funcionam como preenchedores de $\mathrm{C}$, fechando a projeção estendida de um verbo no infinitivo. O infinitivo é uma forma nominal selecionada por um $\mathrm{C}$ nulo ou um C preenchido por uma preposição funcional.

A diferenciação entre preposições lexicais e funcionais acima proposta pode ser visualizada na representação:

PREPOSIÇÕES LEXICAIS

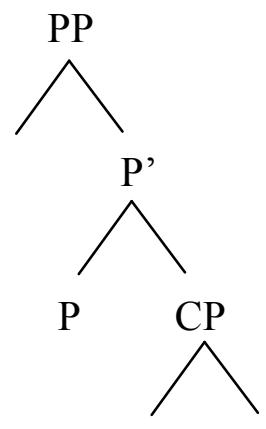

PREPOSIÇÕES FUNCIONAIS
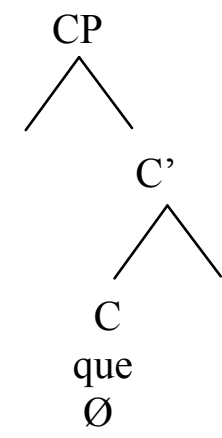

Prep.funcional
[+FIN]

[- FIN]

[- FIN]

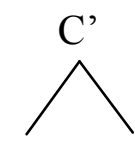

$\mathrm{C}$

que

$\varnothing$ 
Em artigo de 1989, Rocha estabelece uma relação entre o fato de a preposição funcionar como complementizador (substituindo a flexão) com o fenômeno de desprodropização no PB. Para a autora há evidências de que os fatos abaixo são instâncias deste fenômeno:

1. Preposição funcionando como complementizador, substituindo a flexão;

2. Ocorrência de sujeito lexical nas infinitivas com de;

3. Ocorrência do fenômeno de ECM.

Sua argumentação é pautada na assunção de que o nódulo COMP pode ser preenchido tanto por complementizadores do tipo QUE, como por preposições que parecem ter um comportamento similar ao dos complementizadores, sendo elas: de, para e $a$, as preposições gramaticais. Os resultados encontrados para o PB foram:

- A preposição de nas orações adjetivais possibilita a presença de sujeito lexical, isto é, autoriza a flexão.

- Para e de introduzem orações cujos sujeitos podem apresentar referentes iguais ou diferentes dos da oração matriz, o que comprova que estes elementos não regem a posição de sujeito adjacente e isto constitui evidência para a auto-suficiência das infinitivas.

- A preposição de se comporta como um complementizador de infinitivo;

- A preposição para como preposição-complementizador nos casos de ECM;

- A preposição $a$ é o introdutor básico das orações relativas infinitivas e ocorre em estruturas de controle obrigatório, comportando-se mais como um operador do tipo $\mathrm{WH}$.

Ao estudar construções do tipo fácil/difícil, Rocha (1989) observou que a preposição $d e$, enfraquecida de sua força preposicional, parece não reger nem atribuir Caso ao SN lexical, tendo apenas o papel de autorizar AGR/ INFL. 
III. ANÁLISE DESCRITIVA DOS DADOS 
O objetivo deste capítulo é descrever a estrutura da sentença [-FIN] em que há a inserção do se, bem como definir os contextos mais produtivos dessa inserção. Destarte, elencamos os grupos de fatores e procedemos à computação dos dados. Como primeiro grupo, apresentamos o tipo de verbo, subdividindo em estruturas biargumentais e monoargumentais, como temos em (56) e (57), respectivamente.

(56) "Nos últimos anos, para se estimar a presença de ideação suicida na população geral, grupos de pesquisa têm enviado questionários para serem preenchidos pela população geral."

(Soares, 2003)

(57) "A partir de agora, diversas outras análises devem ser feitas para se chegar a um código-fonte efetivo."

(Berni,2004)

No caso dos verbos biargumentais, como é previsto o preenchimento do argumento interno, imaginamos que haveria diferença de comportamento em relação à concordância. Esperávamos encontrar quatro possibilidades de preenchimento - duas estabelecendo concordância e duas sem concordância.

\section{CONCORDÂNCIA}

Verbo biargumental no singular - argumento no singular

Verbo biargumental no plural- argumento no plural

\section{NÃO-CONCORDÂNCIA}

Verbo biargumental no singular - argumento no plural

Verbo biargumental no plural - argumento no singular 
Porém, essa análise se demonstrou infrutífera, visto não terem sido encontrados exemplos de concordância no plural. Os dados encontrados no corpus com verbos biargumentais seguem o modelo abaixo:

\section{Verbo no singular - argumento no singular}

(58) "Esse fato é essencial para se entender a contaminação excessiva que a racionalidade econômica desencadeia nos debates internacionais (...)"

(Pessoto, 2001)

\section{Verbo no singular - argumento no plural}

(59) “ (...) tem expectativa alta com relação à obtenção de upgrade tecnológico, uma vez que é real a possibilidade de se contratar fornecedores externos mais bem preparados."

(Perez, 2003)

Observe-se que, nos exemplos, o verbo mantém-se no infinitivo ${ }^{27}$. Em (58), o argumento interno "a contaminação excessiva", apresenta-se no singular; e, em (59), "fornecedores externos mais bem preparados", apresenta-se no plural. Pela gramática tradicional (GT), o SN posposto seria considerado sujeito gramatical da oração e deveria concordar em número com o verbo, o que ocasionaria a flexão do verbo, gerando um infinitivo flexionado, como teríamos em (59a).

(59a) (...) a possibilidade de se contratarem fornecedores externos (...)

No entanto, em nenhuma sentença do corpus ocorre infinitivo flexionado. O verbo não se flexiona e, em todos os exemplos, o se aparece anteposto ao verbo ${ }^{28}$.

Com relação aos verbos monoargumentais, que apresentam apenas um argumento; o interno ou o externo, foram agrupados separadamente por se tratarem de casos inovadores. De fato, a GT não dispõe do uso do se no contexto de verbos

\footnotetext{
${ }^{27}$ Podemos deduzir que o verbo em (52) apresenta-se no infinitivo impessoal pela falta de concordância com o argumento interno. Em (51), não é possível determinar, embora possamos inferir que se trata de um uso similar.

${ }^{28}$ Vide nota anterior.
} 
monoargumentais. Nessa modalidade, contabilizamos tanto os verbos inergativos ${ }^{29}(60)$, quanto os inacusativos $^{30}(61)$.

(60) “(...) a necessidade de se lutar por educação (...)."

(Ribeiro, 2001)

(61) "Para se chegar às soluções, a pesquisa é um excelente meio."

(Perez, 2003)

Assim, a amostra constitui-se de 120 dados de se em contextos de verbos [-FIN], distribuídos, portanto, como demonstrado acima, entre verbos biargumentais e monoargumentais. Tal divisão teve a intenção de determinar em termos estatísticos a maior e menor incidência da ocorrência do fenômeno de inserção do se junto a verbos infinitivos.

Observou-se que tanto verbos de dois argumentos, quanto verbos de um argumento vêm licenciando o se em construções não-finitas. A tabela 1 mostra, em termos numéricos, como se dá a distribuição do se quanto à estrutura argumental dos verbos:

Tabela 1- ESTRUTURA ARGUMENTAL DOS VERBOS

\begin{tabular}{|c|c|c|}
\hline $\begin{array}{c}\text { ESTRUTURA } \\
\text { ARGUMENTAL } \\
\text { DOS VERBOS }\end{array}$ & OCORRÊNCIAS & FREQÜÊNCIA \\
\hline Biargumental & 104 & $86.6 \%$ \\
\hline Monoargumental & 16 & $13.4 \%$ \\
\hline TOTAL & 120 & $100 \%$ \\
\hline
\end{tabular}

29 A subdivisão entre verbos inergativos e inacusativos seguiu os testes propostos por Eliseu (1984).

${ }^{30}$ Não se tem a intenção de analisar o peso que os verbos inacusativos vêm ganhando no preenchimento desse tipo de estrutura. Fica a cargo de estudos posteriores uma análise mais aprofundada da introdução dessa categoria de verbos em sentenças [-FIN]. 
Há um grande percentual de incidência do se com verbos biargumentais, ocorrência em termos percentuais de 86,6. Ainda que a grande maioria de estruturas [-FIN] com se ocorra com verbos biargumentais, não podem ser descartados os 13,4\% de ocorrência de verbos monoargumentais, pois se tratam de uma novidade no sistema.

Observe-se que, nos casos de verbos monoargumentais, o se é inserido na posição prototípica de sujeito, assim como ocorre nos casos de verbos biargumentais. Em nenhum exemplo encontrado, o se aparece em posição pós-verbal. Essa nova distribuição sugere a necessidade de uma análise quantitativa que mostre a atuação da estrutura argumental do verbo no preenchimento da posição pré-verbal do verbo [-FIN], uso não previsto pela gramática normativa.

\subsection{FATORES PARA APOSIÇÃO DE SE EM ESTRUTURAS BIARGUMENTAIS E MONOARGUMENTAIS [-FIN]}

Os dados apresentados na tabela 1, na introdução deste capítulo, demonstram que tanto verbos biargumentais, quanto verbos monoargumentais aceitam aposição do se. Se a ocorrência já se estende a qualquer tipo de verbo, é preciso verificar qual é o elemento que proporciona a sua entrada.

Por esse motivo, procedemos à observação do comportamento dos elementos que precedem o se nessas construções. Percebemos que o elemento anterior ao se, na maioria absoluta dos casos, é uma preposição. Assim, elencamos como segundo fator a presença ou não de uma preposição. Procuramos observar qual o tipo mais recorrente e a porcentagem de seu uso. Nos exemplos (62) e (63), temos, respectivamente, casos de verbos biargumentais e monoargumentais antecedidos desse elemento:

(62) "Processo construtivo é um organizado e bem definido modo de se construir um edifício."

(Martins, 2004) 
(63) "As dificuldades para se chegar a uma universidade como professor são tão grandes, que (...)"

(Ribeiro, 2001)

Já no exemplo (64), está arrolado o único exemplo de verbo biargumental sem preposição:

(64) “(...) por me fazer crer que é possível se alcançar os objetivos profissionais com ética e satisfação."

(Giovaninni, 2003)

Além de preposição, foram encontrados cinco casos de que precedendo o se. Vejamos quais são eles e por que foram tratados à parte:

(65) “E, apesar de pouco expressivos, há que se considerar também a ação dos fabricantes de painéis pré-fabricados (...)"

(Martins, 2004)

(66) "Mas enquanto o Estado não encontra o caminho (...) que dê competência a seus alunos, há que se criar critérios para a inserção destes nas universidades públicas."

(Ribeiro, 2001)

(67) "Na definição das diretrizes curriculares nacionais para a educação profissional de nível técnico há que se enfatizar o que dispõe a LDB/96 em seus artigos 39 a 42, (...)” (Kobayashi, 2002)

(68) "E ainda, atualmente, com o currículo estruturado em função de competências que se deseja desenvolver no futuro TE, há que se discutir sobre o que é competência (...)" (Kobayashi, 2002)

(69) “(...) há que se partir do reconhecimento da individualidade do aluno e procurar desenvolver suas potencialidades."

(Kobayashi, 2002) 
Dos exemplos (65) a (69), o elemento que, licenciador da flexão, parece se comportar, nesses casos, como preposição, pois é uma expressão equivalente a tem de. Por fugir à alçada de nosso trabalho, não analisaremos esse elemento.

A fim de observar em termos estatísticos a incidência de preposição, rastreamos, na Tabela 2, a relação entre a estrutura argumental do verbo e a presença ou ausência de preposição. Os 115 dados encontram-se distribuídos a seguir:

Tabela 2- PRESENÇA X AUSÊNCIA DE PREPOSIÇÃO

\begin{tabular}{|l|rr|lr|c|}
\hline & \multicolumn{2}{|c|}{ PRESENÇA } & \multicolumn{2}{|c|}{ AUSÊNCIA } & TOTAL \\
& $\mathrm{n}^{\circ}$ & $\%$ & $\mathrm{n}^{\circ}$ & $\%$ & \\
\hline Biargumental & 102 & 99.0 & 01 & 1.0 & 103 \\
\hline Monoargumental & 12 & 100.0 & 00 & 0.0 & 12 \\
\hline TOTAL & 114 & $99.1 \%$ & 01 & $0.9 \%$ & 115 \\
\hline
\end{tabular}

A tabela mostra que o se é precedido categoricamente pela categoria preposicional: $99.1 \%$ do total geral de estruturas analisadas. A presença da preposição é atuante tanto no contexto de verbos biargumentais, quanto no contexto de verbos monoargumentais. Ressalte-se a existência de um único caso de verbo biargumental sem a preposição, e de nenhum caso de verbo monoargumental nessa mesma circunstância. Reproduzimos o exemplo abaixo:

(70) “(...) por me fazer crer que é possível _ se alcançar os objetivos profissionais com ética e satisfação."

(Giovaninni 2003)

Como na amostra há uma ampla variedade de preposições, fez-se necessário verificar a distribuição dos 114 casos de se em contextos de preposição, observando a recorrência de cada uma delas. Observemos a tabela 3. 
Tabela 3- DISTRIBUIÇÃO DAS PREPOSIÇÕES X ESTRUTURA ARGUMENTAL

\begin{tabular}{|l|cc|cc|cc|cc|cc|cc|c|}
\hline & \multicolumn{2}{|c|}{ DE } & \multicolumn{2}{|c|}{ PARA } & \multicolumn{2}{|c|}{ A } & \multicolumn{2}{|c|}{ EM } & \multicolumn{2}{|c|}{ SEM } & \multicolumn{2}{|c|}{ LOCUÇÃO } & TOTAL \\
& $\mathrm{n}^{\circ}$ & $\%$ & $\mathrm{n}^{\circ}$ & $\%$ & $\mathrm{n}^{\circ}$ & $\%$ & $\mathrm{n}^{\circ}$ & $\%$ & $\mathrm{n}^{\circ}$ & $\%$ & $\mathrm{n}^{\circ}$ & $\%$ & $\mathrm{n}^{\circ}$ \\
\hline Biargumental & 49 & 48,1 & 22 & 21,6 & 10 & 9,8 & 6 & 5,8 & 0 & 0 & 15 & 14,7 & 102 \\
\hline Monoargumen. & 03 & 25,0 & 06 & 50,1 & 01 & 8,3 & 0 & 0 & 01 & 8,3 & 01 & 8,3 & 12 \\
\hline TOTAL & 52 & 45,6 & 28 & 24,6 & 11 & 9,6 & 6 & 5,3 & 01 & 0,9 & 16 & 14,0 & 114 \\
\hline
\end{tabular}

Primeiramente, no caso dos verbos biargumentais, a leitura horizontal da tabela mostra que de é a preposição mais freqüente na construção se V-Fin, $(48,1 \%)$, seguido da preposição para $(21,6 \%)$. No caso de verbos monoargumentais, a mais recorrente é inversamente a preposição para $(50,1 \%)$, seguida da preposição de $(25,0 \%)$. No cômpito geral, a leitura vertical mostra que essas duas preposições são as mais recorrentes (de: 45,6\% e para 24.6\%). Assim, com os verbos biargumentais, a preposição de é a que tem maior incidência no uso de se; com os monoargumentais, a preposição para é a que tem o maior peso no uso de se. Apesar disso, uma e outra preposição são usadas com os dois tipos de verbos.

As sentenças (71) e (72) ilustram a ocorrência dessas preposições:

(71) "A difícil decisão de se contratar fornecedores de serviços (...)"

(Perez, 2003)

(72) "Para se estabelecer os valores normais das variáveis analisadas (...)"

(Giovaninni, 2003)

Além de preposições simples ${ }^{31}$, atestamos a freqüência de algumas locuções, que nas estruturas biargumentais atingem $14,7 \%$ das ocorrências; e, entre os verbos monoargumentais, 8,3\%. Essas, apesar de constarem em um número relativamente inferior ao das preposições simples de e para, abriram caminho para uma nova reflexão, a saber, o valor semântico expresso por esses elementos, como tempo, finalidade. Destacamos como exemplos, com valor final: a fim de, com o intuito de, com vistas a,

\footnotetext{
${ }^{31} \mathrm{Na}$ GT, chamadas de preposições essenciais.
} 
com o propósito de, com o objetivo de; e, com valor temporal: no momento de, antes de. Em (73), temos um caso de locução prepositiva com valor temporal:

(73) “(...) sendo que o preço do componente em si tem grande peso no momento de se definir por este ou aquele fabricante, (...)"

(Martins,2004)

No exemplo acima, a locução prepositiva poderia ser trocada, sem substancial perda do conteúdo informativo, pela preposição $a$, que também expressa valor temporal ${ }^{32}$.

(74a) “(...) sendo que o preço do componente em si tem grande peso ao se definir por este ou aquele fabricante, $(\ldots)$ "

O próximo passo foi observar as categorias anteriores à preposição. Nesse momento, a intenção foi verificar se na oração matriz havia um elemento como nome, adjetivo, verbo ou uma categoria nula atuando de maneira massiva. Seguem, a título de ilustração, exemplos das categorias elencadas:

\section{NOME}

(75) “(...) projetos incompletos e a necessidade de se tomar decisões na obra ou interromper os serviços."

(Martins,2004)

\section{ADJETIVO}

(76) (...) úteis para se avaliar a verdadeira aderência ao tratamento (...)

(Soares, 2003)

\section{VERBO}

(77) "Uma das técnicas freqüentes consiste em se usar uma matriz BCG, (...)"

(Perez, 2003)

\footnotetext{
${ }^{32}$ Quanto à função final e temporal das preposições (não das locuções), ela será objeto de análise mais à frente.
} 


\section{CATEGORIA NULA}

(78) "Quais são os componentes de tecnologia da informação que estão sendo terceirizados, _ ao se contratar serviços de TI?"

(Perez, 2003)

Dessa maneira, observamos os elementos da sentença matriz que poderiam proporcionar a escolha/ entrada dessas preposições. Cruzamos esses elementos com as preposições mais recorrentes: de, para, $a$, estabelecendo uma tabela para cada tipo de preposição. Assim, na tabela 4, observamos o elemento que precede o de, que é a mais recorrente na amostra, com 52 ocorrências. Para estabelecer um paralelismo com as tabelas anteriores, achamos relevante manter a distinção entre verbos monoargumentais e biargumentais. Os percentuais encontram-se a seguir:

Tabela 4- ANTECEDENTE DA PREP. DE X ESTRUTURA ARGUMENTAL

\begin{tabular}{|c|c|c|c|c|c|c|c|c|c|}
\hline & \multicolumn{2}{|c|}{ NOME } & \multicolumn{2}{|c|}{ ADJETIVO } & \multicolumn{2}{|c|}{ VERBO } & \multicolumn{2}{|c|}{$\varnothing$} & \multirow{2}{*}{$\begin{array}{c}\text { TOTAL } \\
n^{\circ}\end{array}$} \\
\hline & $\mathrm{n}^{\circ}$ & $\%$ & $n^{\circ}$ & $\%$ & $n^{\circ}$ & $\%$ & $\mathrm{n}^{\circ}$ & $\%$ & \\
\hline Biargumental & 46 & 93,9 & - & - & 03 & 6,1 & - & - & 49 \\
\hline Monoargumental & 03 & 100 & - & - & - & 0 & - & - & 03 \\
\hline TOTAL & 49 & 94,2 & - & - & 03 & 5,8 & - & - & 52 \\
\hline
\end{tabular}

Os dados mostram que o elemento que precede a preposição de é na maioria das vezes um nome, ocorrendo em 94,2\% dos casos. Galves (1997) observa o emprego de se $\mathrm{V}[-\mathrm{FIN}]$ com estruturas do tipo "difícil de", isto é, estruturas adjetivais. No entanto, em nosso corpus, não foi encontrado nenhum caso de adjetivo + preposição. Assim como o adjetivo, a categoria nula não propiciou o uso de 'de'seguido de $s e V$-FIN.

A leitura vertical sugere que a categoria nome é fortemente presente tanto em estruturas com verbos biargumentais, 93,9\%; como em estruturas com verbos monoargumentais, $100 \%$ dos casos. Saliente-se, porém, o número baixo de ocorrências, apenas 03. O exemplo a seguir ilustra o tipo de estrutura mais recorrente junto à preposição de, a associação de um nome com a preposição. 
(79) “A necessidade de se fortalecer o planejamento é expresso no documento "La Planificación em Salud".

(Pessoto,2001)

No exemplo (80), temos a utilização de uma estrutura monoargumental, antecedida de nome e preposição de.

(80) "Em oposição a essa apatia que assolava a maioria dos negros, os jornais destinados a esse segmento travam uma verdadeira campanha de esclarecimento e apontavam aos negros a necessidade de se lutar por educação e pela educação de seus filhos, (...)" (Ribeiro,2001)

E, no exemplo (81), a estrutura biargumental antecedida de verbo e preposição de.

(81) "Há de se enfatizar, ainda, a composição do ovo, que possui, na gema, (...)" (Toledo,2003)

Passemos agora a observar o termo precedente à preposição para, que ocorre em $24,6 \%$ dos dados analisados.

Tabela 5- ANTECEDENTE DA PREP.PARA X ESTRUTURA ARGUMENTAL

\begin{tabular}{|c|c|c|c|c|c|c|c|c|c|}
\hline & \multicolumn{2}{|c|}{ NOME } & \multicolumn{2}{|c|}{ ADJETIVO } & \multicolumn{2}{|c|}{ VERBO } & \multicolumn{2}{|c|}{ NULO } & \multirow{2}{*}{$\begin{array}{c}\text { TOTAL } \\
n^{\circ}\end{array}$} \\
\hline & $n^{\circ}$ & $\%$ & $\mathrm{n}^{\circ}$ & $\%$ & & $\%$ & $\mathrm{n}^{\circ}$ & $\%$ & \\
\hline Biargumental & 09 & 40,9 & 02 & 9,1 & - & & 11 & 50,0 & 22 \\
\hline Monoargumental & 05 & 83,3 & - & & - & & 01 & 16,7 & 06 \\
\hline TOTAL & 14 & 50,0 & 02 & 7,1 & - & & 12 & 42,9 & 28 \\
\hline
\end{tabular}

Em relação ao para, nas estruturas biargumentais, a categoria nula vem em primeiro lugar, com 50,0\% das ocorrências, seguida da categoria nome com 40,9\%. Nas estruturas monoargumentais, obtivemos $83,3 \%$ da categoria nome, seguida de $16,7 \%$ de categoria nula. No cômpito geral, a categoria nome mantém-se como a mais recorrente com preposição, 50\% dos casos, seguido do nulo com 42,9\%. Ocorreram apenas dois 
casos de adjetivo antecedendo a preposição para, 7,1\%, e estes ocorreram junto a estruturas biargumentais. Não houve nenhum caso do antecedente da preposição ser um verbo.

Em (82) e (83), temos exemplos da preposição para antecedida pela categoria nome:

(82) "Se o ser fosse apenas o que é, não haveria nem sequer lugar para se falar dele." (Arruda,2001)

(83) "O tempo investigado é um importante fator para se avaliar a prevalência de ideação suicida."

(Soares,2003)

Em (84), antecedida pela categoria nula:

(84) "Para se alcançar os objetivos pretendidos buscou-se identificar as razões que motivaram a decisão do fornecedor de investir."

(Martins,2004)

A seguir, a tabela 6 computou a freqüência da preposição $a$, que é a terceira mais recorrente no corpus, com 9,6\% das ocorrências.

Tabela 6- ANTECEDENTE DA PREP. $A$ X ESTRUTURA ARGUMENTAL

\begin{tabular}{|c|c|c|c|c|c|c|}
\hline & NOME & ADJETIVO & VERBO & \multicolumn{2}{|c|}{ NULO } & \multirow{2}{*}{$\begin{array}{c}\text { TOTAL } \\
n^{\circ}\end{array}$} \\
\hline & $\mathrm{n}^{\circ} \quad \%$ & $n^{\circ}$ & $n^{\circ}$ & $n^{\circ}$ & $\%$ & \\
\hline Biargumental & - & - & - & 10 & 90.9 & 10 \\
\hline Monoargumental & - & - & - & 01 & 9.1 & 01 \\
\hline TOTAL & - & - & - & 11 & 100 & 11 \\
\hline
\end{tabular}

Todos os casos de preposição $a$ ocorreram categoricamente com elemento nulo. Não se observou nenhum preenchimento por nome, adjetivo ou verbo, diferentemente das preposições de e para. 
Assim, procedemos a uma comparação entre as tabelas 4,5 e 6 para visualizar as diferenças de preenchimento encontradas. Observamos que junto à preposição de, ocorre a categoria nome, seguida da categoria verbo; não ocorrendo adjetivo ou categoria nula. Com a preposição para, a categoria nome compete com o elemento nulo, seguido de longe da categoria adjetivo. Assim como com a preposição de, a categoria nula também não ocorre com preposição para. Em contraposição, a preposição $a$ ocorre apenas com esta categoria.

Quanto à categoria nula, vejamos que esta corresponde à preposição encabeçando sentença, como vemos nos exemplo abaixo:

(85) "Ao se utilizar um determinado método de clusterização, uma solução possível é determinar os agrupamentos de entrada, (...)"

(Berni, 2004)

Considerando, ainda, a semântica e assumindo aqui a nomenclatura usada pela GT, a oração sublinhada em (85) é exemplo de uma subordinada temporal reduzida de infinitivo, o que equivale dizer que esta se associa a uma oração principal em condição de adjunção.

(86) "Antes de se iniciar a programação do algoritmo "Regras Limitadas", foi necessário testar e validar os subsistemas de conversão (...)"

(Berni, 2004)

(87) "Para se estabelecer os valores normais das variáveis analisadas, a partir de gatos hígidos, foram calculados os valores obtidos (...)"

(Giovaninni, 2003)

Em (86), a oração "antes de se iniciar a programação do algoritmo "Regras Limitadas" adjunge-se fornecendo um valor temporal; e (87), "para se estabelecer os valores normais das variáveis analisadas”, com valor final. O que estabelece essa relação é a preposição ou locução prepositiva presente em cada uma das orações, "antes de"e "para". 
Assim, da análise das três preposições mais recorrentes no corpus de, para e $a$, estabeleceu-se uma correlação entre preposições e tipos de oração, o que pode ser visto no quadro a seguir:

\begin{tabular}{|c|c|}
\hline PREPOSIÇÃO & INTRODUZ ORAÇ̃̃o \\
\hline DE & COMPLETIVA NOMINAL \\
\hline PARA & FINAL \\
\hline A & TEMPORAL \\
\hline
\end{tabular}

Dessa relação entre preposições e tipos de oração, podemos depreender que estamos diante de dois tipos de estruturas de complementação. A primeira expressa pelas orações completivas nominais, e, a segunda, por estruturas em adjunção, com as orações finais e temporais.

\section{GRUPO 1 - COMPLETIVAS DE NOME}

(88) “A necessidade de se investir em Tecnologia da Informática é inquestionável."

(Perez,2003)

\section{GRUPO 2 - ADJUNTIVAS FINAIS E TEMPORAIS}

(89) “(...) quais as estratégias que você utiliza para se permanecer no campo?”

(Ribeiro,2001)

(90) “(...) cujo objetivo seria prevenir grandes aumentos da pressão arterial ao se aumentar a ingestão de sódio."

(Silva,2001)

A presença de certas locuções prepositivas "antes de, com o intuito de, com a finalidade de, entre outras", também ratifica a presença de tipos específicos de orações no corpus e sua correlação com a entrada da partícula se. 
Produzimos, na seqüência, uma tabela apresentando a distribuição dos tipos de orações no corpus. Elencamos, em um primeiro plano, as orações completivas nominais, seguidas das adjuntivas finais, temporais, sem deixar de lado "outras",33, que por representarem um número muito ínfimo, foram agrupadas sem uma categorização mais definida.

Tabela 7- TIPOS DE ORAÇÕES X ESTRUTURA ARGUMENTAL

\begin{tabular}{|c|rr|rr|rr|rr|c|}
\hline & \multicolumn{2}{|c|}{$\begin{array}{c}\text { COMPLETIVA } \\
\text { NOMINAL }\end{array}$} & \multicolumn{2}{|c|}{ FINAL } & \multicolumn{2}{|l|}{ TEMPORAL } & \multicolumn{2}{|l|}{ OUTRAS } & TOTAL \\
& $\mathrm{n}^{\circ}$ & $\%$ & $\mathrm{n}^{\circ}$ & $\%$ & $\mathrm{n}^{\circ}$ & $\%$ & $\mathrm{n}^{\circ}$ & $\%$ & $\mathrm{n}^{\circ}$ \\
\hline Biargumental & 51 & 50,0 & 32 & 31,4 & 12 & 11,8 & 07 & 6,8 & 102 \\
\hline Monoargumental & 05 & 38,4 & 05 & 38,4 & 03 & 23,2 & 0 & 0 & 13 \\
\hline TOTAL & 56 & 48,7 & 37 & 32,1 & 15 & 13,1 & 07 & 6,1 & 115 \\
\hline
\end{tabular}

O maior número de casos de inserção do se encontra-se entre as orações completivas nominais, configurando $48,7 \%$ do total de dados analisados - $50,0 \%$ entre as estruturas biargumentais, e $38,4 \%$ entre as monoargumentais. Seguem-se as orações finais com 32,1\%, sendo 31,4 nas biargumentais e 38,4\% nas monoargumentais e, em seguida, as temporais, 13,1\%, configurando $11,8 \%$ entre os verbos biargumentais e $23,2 \%$ entre os monoargumentais. Se descartarmos o grupo "outras" e separarmos em dois grupos, colocando as completivas nominais no grupo das estruturas de complemento e as finais e temporais no grupo das estruturas adjuntivas, obteremos $51,8 \%$ para as estruturas completivas e $48,2 \%$ para as adjuntivas, o que nos mostra que existe um equilíbrio na introdução do se nesses dois grupos.

$\mathrm{Na}$ seção seguinte, abordaremos a entrada do se nesses três tipos de orações, acrescentando, ainda, como um último fator, a referencialidade da oração matriz. As discussões serão feitas com base nos resultados de testes de produção realizados junto aos alunos de Letras.

\footnotetext{
${ }^{33}$ Entre elas, orações completivas de verbos. Ex. "A primeira delas consiste em se avaliar a faixa de valores das variáveis de interesse.”(Berni, 2004)
} 


\subsection{OUTROS DADOS}

A formalidade do texto foi um fator relevante para a observação dessa novidade no sistema, visto que a entrada do se em estruturas [-FIN] refere-se a uma estratégia de indeterminação. $\mathrm{O}$ texto acadêmico, por se tratar de um gênero em que se faz necessário o uso de uma linguagem impessoal, proporciona, ao lado de zero e de outras estratégias de indeterminação, a inserção do se, utilização não prevista pela gramática normativa, mas, ao mesmo tempo, não estigmatizada.

No entanto, apesar de não termos procedido a uma análise variacionista, pudemos observar que essa estratégia de indeterminação vem sendo usada com muita freqüência, não só na língua escrita formal, como estratégia já amplamente difundida na língua escrita, mas também como estratégia de indeterminação em outros gêneros e até mesmo na língua falada. Assim, abaixo elencamos alguns exemplos de uso de se em estruturas [-FIN] estabelecendo leitura indeterminada. Com base no material recolhido em (C2), procedemos a uma observação do comportamento do $s e \mathrm{~V}-\mathrm{FIN}$ em outros contextos que não as dissertações colhidas no sistema SIBI-NET, e comparamos as estratégias de inserção elencadas em (C1) a fim de proceder a uma análise um pouco mais ampla dessa variação.

Em propaganda veiculada durante a campanha para o Governo do Estado de São Paulo, o candidato José Serra, proferiu o seguinte discurso:

(91) "A intenção é transformar Paraisópolis em um bairro com (...), serviço social para se viver aqui em São Paulo."

(Candidato José Serra - Jornal da Globo, 05/07/2005)

Observe que o verbo "viver" é inacusativo, a preposição "para" tem valor final.

Em artigo produzido para a revista acadêmica História Viva, novamente a presença do verbo viver: 
(92) “Na visão da historiadora Lucy Maffei Hutter, havia nos países emigrantistas duas correntes propagandistas opostas sobre o Brasil, as que o apresentavam como "paraíso na terra"e as que o consideravam um lugar péssimo para se viver, atrasado, "cheio de moléstias (febre amarela, malária) e negros"."

(Revista História Viva - R.Dezem)

Em um folheto publicitário de uma empresa de estética, constava:

(93) "Nova versão de se comer legumes acompanhados deste delicioso creme!"

(Vigilantes do Peso)

Em (93), o verbo comer não estabelece concordância com o argumento interno no plural, propiciando a leitura ativa. A preposição de é posposta ao nome versão, o caso mais encontrado em nossa análise quantitativa.

No jornal Folha de São Paulo, de ampla circulação:

(94) "Essa segunda hipótese é a mais favorecida hoje, pelos autores do estudo, mas que também afirmam que será preciso aprofundar as investigações para se chegar a uma conclusão definitiva."

(Folha de São Paulo,20/11/2004)

No exemplo do jornal, usa-se o verbo inacusativo "chegar". A encaixada é introduzida pela preposição para, com valor final.

Em jornal do bairro da Freguesia do Ó:

(95) “(...) mas é bom ver se a escola tem também uma preocupação em promover junto aos alunos a solidariedade e a ética - fundamentais para se formar bons cidadãos desde a mais tenra idade."

(FregNews, 06/11/2004)

(96) "No geral, é bom aos pais ter claro o que se quer da escola."

(FregNews, 06/11/2004) 
Atestamos também a ocorrência do se indeterminador em redações de alunos do Ensino Fundamental e Médio:

(97) “(...) percebi que era bem forte, bem mais forte que pensava, mas nada impossível de se passar por."

(98) "Sou ser humano e tenho imperfeições, talvez realmente intoleráveis para se conviver com elas."

(99) “Informação, comunicação: Leis dificeis de se lidar." (título)

(100) "Esta é uma pergunta dificil de se responder."

(101) “(...) é um meio de se resolver alguma coisa.”

(102) "Tudo se gera a fim de se reverter em lucros."

(103) "A melhor maneira de se haver liberdade de informação é cada um refletir um pouco."

(104) "Poder fazer o que tem vontade por mais que seja barrado merece privacidade, coisa dificil de se conseguir."

(105) "Procurando construir a pura liberdade de se expressar, de se opinar e de se mostrar capaz."

Note que nos exemplos colhidos entre alunos, ocorreu mais de uma vez a construção adjetival "difícil de", o que não havia ocorrido em nosso corpus. A explicação que pode ser dada refere-se ao fato que, na linguagem acadêmica, busca-se a impessoalidade: adjetivos como difícil, fácil, legal, bom, etc. expressam juízos de valor, o que está em contradição com a linguagem impessoal de textos que se pautam na objetividade. 
Assim, para a abordagem dos tipos de oração que procederemos no próximo capítulo, agregamos às orações completivas de nome as orações completivas de adjetivo, porque ambas apresentam, conforme a análise de nossos dados, a posposição da preposição de. Para finalizar, pareceu-nos que $(\mathrm{C} 2)$ apresentou exemplos que ratificam a análise inicial de Galves (1987) sobre a inserção de se em construções "difíceis". Nossa escolha por um gênero textual específico, no entanto, ampliou os contextos dessa inserção.

\subsection{CONSIDERAÇÕES FINAIS DO CAPÍTULO}

As análises procedidas neste capítulo abrem alguns esclarecimentos sobre a inserção do se em estruturas [-FIN]. Na formação do corpus de análise (C1), não foi encontrado nenhum caso de inserção de se em estruturas [-FIN] em que o verbo estabelecesse concordância com o argumento interno no plural, o que seria esperado caso a estrutura fosse interpretada como passiva. Por não terem sido encontrados exemplos de concordância no plural, refuta-se a idéia de Duarte $(2000,2002)$ de que, nas sentenças [-FIN], o se vem passando de indeterminador a apassivador.

Fator condicionante do uso do se é seu aparecimento em construções subordinadas [-FIN] encabeçadas por preposição, ocorrendo em 99,1\% das estruturas analisadas. A existência de um único caso de ausência de preposição ocorreu junto a um verbo biargumental, não tendo sido registrado nenhum caso de verbo monoargumental nessa mesma circunstância.

Verificamos a distribuição das preposições em relação à estrutura argumental e chegamos ao resultado de que junto a verbos monoargumentais, a preposição que mais ocorre é de, seguida da preposição para. Ao contrário, nas estruturas monoargumentais, a preposição mais encontrada foi para, seguida da preposição de. A preposição $a$ obteve o mesmo índice percentual junto a estruturas biargumentais e monoargumentais $9,8 \%$ e $8,3 \%$, respectivamente. Outras preposições figuraram no corpus, são elas em e sem, no entanto, os números foram irrisórios. 
Além da análise categorial que procedemos, observamos também a função semântica veiculada por essas preposições, chegando à conclusão de que elas estabelecem um número limitado de relações semânticas. Na grande maioria dos casos, valores temporais e finais. A preposição, ainda, serve como introdutor do complemento do nome ou adjetivo presente na oração matriz. Dessa forma, pudemos elencar dois grupos diferentes de orações infinitivas: o das completivas, que compreendem as orações completivas de nome e adjetivo; e o das adjuntivas, que compreendem as orações subordinadas adverbiais finais e temporais. Esse fator foi extremamente importante, pois possibilitou a análise de diferentes tipos de preposição.

Os dados nos mostram que as preposições se comportam de maneira diferenciada. De ocorre categoricamente na presença de um elemento anterior $(94,2 \%$ com nomes, e $5,8 \%$ com verbos). Inferimos daí que a preposição de apresenta-se como um $\mathrm{X}^{\circ}$. A preposição $a$, em contrapartida, não ocorre com nenhuma categoria anterior. Assim, encontra-se sempre em condição de adjunção, no nível XP. Já a preposição para tem como antecedente a categoria nome ou a categoria nula. Por seu comportamento diferenciado, podemos dizer que é um elemento entre complemento e adjunto encontrando-se entre X ${ }^{\circ}$ e XP, como já assinalava Rocha (1989) para essa preposição. Vejamos o quadro:

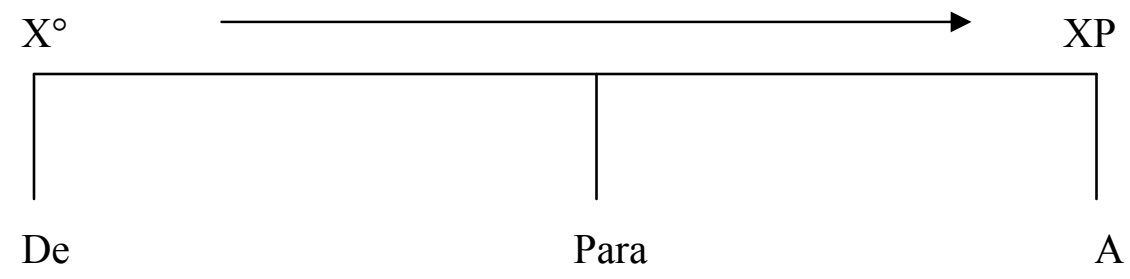

Com o quadro acima, pudemos fazer algumas inferências sobre o tipo de estrutura que analisamos: [X prep se [-FIN]]. Sobre o primeiro grupo, o das orações completivas, observamos que, diferentemente das análises feitas até agora sobre o fenômeno, que atrelavam a inserção do se às estruturas adjetivas do tipo é difícil de, em 48,7\% do total de dados analisados, a inserção está atrelada a orações completivas de nome. Assim temos que, a sentença [-FIN] que complementa o nome é introduzida pela preposição funcional de. Respaldando-nos em Mioto \& Kato (2002), segundo os quais o CP 
infinitivo necessita de uma preposição funcional para fechar sua projeção estendida, observamos que nas construções completivas, a preposição de tem essa função.

Quanto às orações encaixadas adverbiais, há uma predileção pelo emprego de uma preposição lexical, selecionando diretamente um $\mathrm{CP}$ com núcleo nulo. Trata-se de construções que estabelecem relações finais e temporais veiculadas por locuções prepositivas (antes de, com o intuito de, no sentido de), e pelas preposições simples correspondentes (para e $a$ ) que foram reanalisadas como preposições $\{+C\}$, isto é, que tomam como complemento um CP.

Uma última consideração em relação aos resultados encontrados nessa amostra diz respeito à seleção do corpora. A escolha de um corpus formado por textos científicos (C1) foi determinante na observação dessa novidade no sistema, visto que a entrada do se em estruturas [-FIN] refere-se a uma estratégia de indeterminação. $O$ texto acadêmico, por se tratar de um gênero em que se faz necessário o uso de uma linguagem impessoal, proporciona a inserção do se, que é uma utilização não prevista pela gramática normativa, embora não estigmatizada, dada sua prescrição em sentenças [+FIN]. Ao trabalharmos com o segundo corpus (C2), pudemos observar o uso de se em estruturas "difícil de", que não havia ocorrido em (C1), e também constatar que essa inserção está difundida não só na escrita formal, mas também na língua falada, coincidindo os demais os contextos analisados. 
IV.TESTES DE PRODUÇÃO 


\section{IV.TESTES DE PRODUÇÃO}

Neste capítulo, descrevemos os resultados encontrados nos testes de produção. Conforme explicitamos no capítulo II, as sentenças foram divididas em dois grupos, devido às diferentes abordagens previstas.

\subsection{ORAÇÕES EM ADJUNÇÃO}

No primeiro grupo, elencamos sentenças encaixadas adverbiais, para as quais o informante deveria construir uma oração matriz. As sentenças escolhidas para esta abordagem foram S2, S3, S5, S8, S10, S11. Nessa categoria, objetivamos observar a referencialidade que seria atribuída à matriz, tendo em vista que algumas encaixadas apresentavam o se e outras não.

Detivemo-nos, portanto, à observação da referencialidade da matriz, obtendo os seguintes resultados no cômpito geral das orações:

Tabela 8- DISTRIBUIÇÃO DAS ORAÇÕES QUANTO À REF. DA MATRIZ

\begin{tabular}{|c|cc|cc|c|}
\hline & \multicolumn{2}{|c|}{ SUJEITO REF.[+DET] } & \multicolumn{2}{|c|}{ SUJEITO REF.[-DET] } & TOTAL \\
$\mathrm{n}^{\circ}$ & $\%$ & $\mathrm{n}^{\circ}$ & $\%$ & $\mathrm{n}^{\circ}$ \\
\hline$S E$ & 49 & 29 & 119 & 71 & 168 \\
\hline$\varnothing$ & 120 & 71 & 48 & 29 & 168 \\
\hline
\end{tabular}

Verificamos que a distribuição do se ocorre junto a orações matrizes cujo sujeito é referencial [-DET]. O informante relacionou presença de se na oração encaixada à marcação de sujeito [-DET] na matriz em $71,2 \%$ das sentenças analisadas; e, na mesma proporção, relacionou $\varnothing$ da oração encaixada à sujeito [+DET] na oração matriz, 71\% das respostas obtidas. 
Assim, de posse desses resultados gerais, procedemos a um maior detalhamento do grupo das orações adverbiais. Estabelecemos alguns pares comparativos com o intuito de verificar variações relacionadas à estrutura argumental dos verbos dados na encaixada $^{34}$ :

\section{PARALELISMO 1-}

(S10) Ao _ falar de literatura... $\quad \varnothing$

(S3) Ao se falar de filme brasileiro... se

\section{PARALELISMO 2-}

(S2) Antes de _ iniciar o trabalho... $\quad \varnothing$

(S8) Antes de se iniciar a discussão... se

\section{PARALELISMO 3-}

(S5) Depois de _ chegar em casa... $\quad \varnothing$

(S11) Depois de se chegar no trabalho... se

O primeiro paralelismo contempla uma oração adverbial temporal com verbo biargumental e argumento interno dado. Ao inventar uma oração matriz, o informante incorreria na introdução de um sujeito [+DET] ou [-DET] para o verbo escolhido para preenchimento da oração matriz. Na tabela abaixo, descrevemos os resultados encontrados sobre referencialidade da oração matriz no primeiro grupo.

Tabela 9- PARALELISMO 1 (S10-S3)

\begin{tabular}{|l|cc|cc|c|}
\hline & \multicolumn{2}{|c|}{ SUJEITO REF.[+DET] } \\
& $\mathrm{n}^{\circ}$ & \multicolumn{2}{|c|}{ SUJEITO REF.[-DET] } & TOTAL \\
$\%$ & $\mathrm{n}^{\circ}$ & $\mathrm{n}^{\circ}$ \\
\hline (S10) AO _FALAR & 32 & 57.1 & 24 & 42.9 & 56 \\
\hline (S3) AO SE FALAR & 11 & 19.6 & 45 & 80.4 & 56 \\
\hline
\end{tabular}

${ }^{34}$ Tendo em vista a estrutura dada, o verbo falar foi analisado como biargumental (apesar da dupla interpretação que poderia ser atribuída a este verbo). 
Na comparação entre S10 e S3, observamos que o sujeito referencial [-DET] foi muito mais recorrente com a presença do se na encaixada, configurando $80,4 \%$ das ocorrências. Quando a encaixada foi marcada com $\varnothing$, houve uma leve preferência pelo preenchimento com sujeito referencial determinado, $14,2 \%$ pontos a mais sobre a preferência à indeterminação.

(106) Ao se falar de filme brasileiro, critica-se a produção. (se [-DET])

(107) Ao Ø falar de literatura, (eu) sinto enorme prazer. $\quad($ eu $[+\mathrm{DET}])$

No exemplo (106), o informante preencheu a lacuna com um sujeito indeterminado na oração matriz (critica-se). Quando a encaixada apresentou Ø, exemplo (107), o informante preencheu a lacuna com um verbo [+FIN] na $1^{\text {a }}$ pessoa (sinto), determinando o sujeito.

No segundo paralelismo, mantivemos o tipo de oração, isto é, adverbial temporal e escolhemos um verbo biargumental. Nesse item, obtivemos os seguintes resultados:

Tabela 10- PARALELISMO 2 (S2-S8)

\begin{tabular}{|c|cc|cc|c|}
\hline & \multicolumn{2}{|c|}{ SUJEITO REF.[+DET] } \\
$\mathrm{n}^{\circ}$ & \multicolumn{2}{|c|}{$\begin{array}{c}\text { SUJEITO REF.[-DET] } \\
\mathrm{n}^{\circ}\end{array}$} & $\begin{array}{c}\text { TOTAL } \\
\%\end{array}$ & $\mathrm{n}^{\circ}$ \\
\hline (S2) ANTES DE_ INICIAR & 32 & 57.1 & 24 & 42.9 & 56 \\
\hline (S8)ANTES DE $S E$ INICIAR & 17 & 30.4 & 39 & 69.6 & 56 \\
\hline
\end{tabular}

Na comparação feita entre S2 e S8, observou-se que sem o se, 57,1\% apresentam sujeito determinado na matriz, contra $42,9 \%$ de sujeito indeterminado. Com a presença do se, o índice de indeterminação aumentou para 69,6\%.

(108) Antes de Ø iniciar o trabalho, (eu) respirei fundo e me concentrei. (eu [+DET])

(109) Antes de se iniciar a discussão,_é melhor acalmar os ânimos. (Ø [-DET])

(109) Antes de Ø iniciar o trabalho, (nós) falaremos sobre o assunto. (nós [+DET])

(110) Antes de se iniciar a discussão, deve-se estudar o seu tema. (Ø [-DET]) 
O terceiro grupo contemplou a análise de um verbo inacusativo, mantendo o tipo de oração adverbial. Obtivemos:

Tabela 11- PARALELISMO 3 (S5-S11)

\begin{tabular}{|l|lr|lr|c|}
\hline & \multicolumn{2}{|l|}{ SUJEITO REF[+DET] } & \multicolumn{2}{|l|}{ SUJEITO REF[-DET] } & TOTAL \\
& $\mathrm{n}^{\circ}$ & $\%$ & $\mathrm{n}^{\circ}$ & $\%$ & $\mathrm{n}^{\circ}$ \\
\hline (S5) DEPOIS DE _ CHEGAR & 56 & 100 & 0 & 0 & 56 \\
\hline (S11)DEPOIS DE SE CHEGAR & 21 & 37.5 & 35 & 62.5 & 56 \\
\hline
\end{tabular}

O resultado deste terceiro grupo foi bastante interessante, apresentando uma leitura determinada de forma categórica (100\%) na ausência do se. Quando colocada a partícula, a indeterminação ocorreu em $62,5 \%$ dos casos. Vejamos alguns exemplos:

(111) Depois de Ø chegar em casa, (eu) fui tomar banho.

(112) Depois de se chegar no trabalho, pegou-se a pasta.

(113) Depois de Ø chegar em casa, (ele) dormiu.

(114) Depois de se chegar no trabalho, quer-se voltar para casa. (se [-DET])

(115) Depois de Ø chegar em casa, (ele) leu o que pôde.

(116) Depois de se chegar no trabalho, tira-se os sapatos.

$$
\begin{aligned}
& (e u[+\mathrm{DET}]) \\
& (\text { se }[-\mathrm{DET}])
\end{aligned}
$$

$$
(\text { ele }[+\mathrm{DET}])
$$

Os dois primeiros grupos paralelísticos examinados mostram a tendência para a correlação entre $\varnothing$ na oração encaixada e preenchimento de sujeito referencial [+DET] na matriz; assim como presença de se na encaixada e preenchimento de sujeito referencial [-DET]. Entretanto, no terceiro grupo, com a introdução de um verbo inacusativo, $\varnothing$ foi relacionado categoricamente com sujeito [+DET]. Esse resultado mostra o comportamento diferenciado do verbo inacusativo, que parece instituir a regra nas construções V-FIN: se $\varnothing$, então [+DET]. O uso categórico de $\varnothing$ como sujeito referencial determinado sugere que o gatilho da inovação no sistema não está na inserção de se como sujeito indeterminado, mas na interpretação de $\varnothing$ como sujeito determinado com verbos 
não-finitos. Nesse sentido, a inserção de se, é um ajuste no sistema de referencialidade para marcar a indeterminação. Ou seja, a "consolidação" da regra 'se Ø, então [+DET]' ativa a busca de um elemento pleno para marcar a contraparte [-DET]. Este elemento é o se, usado nas sentenças finitas com esse mesmo valor.

\subsection{ORAÇÕES COMPLETIVAS DE NOME E ADJETIVO}

O segundo grupo de sentenças dado como input consistiu de uma oração matriz a qual o informante deveria completar com uma oração. O objetivo era verificar se o nome ou adjetivo da oração matriz acolheria o se na oração [-FIN] encaixada, caso esta fosse produzida $^{35}$. Em três orações, o informante deveria complementar um nome, S4, S9, S13; e, em duas delas, um adjetivo, S6, S12.

\subsubsection{COMPLETIVAS DE NOME}

No grupo das completivas de nome, contrapusemos as sentenças S4 e S13, estruturas em que não era dada nenhuma preposição, à estrutura S9, com o item preposicional dado.

(S4) A probabilidade... é uma em um milhão...

(S9) A chance de .... é mínima...

(S13) A dificuldade... é avaliada pelos economistas...

\footnotetext{
${ }^{35}$ Em alguns casos, o informante preferiu inserir uma palavra que acionava a construção [+FIN].
} 
Verificamos, inicialmente, se houve ou não o preenchimento por preposição, comparando duas sentenças, S4 a S13; e qual o item preposicional usado. Obtivemos os seguintes resultados:

Tabela 12- PREENCHIMENTO DE PREPOSIÇÃO ${ }^{36}(\mathrm{~S} 4-\mathrm{S} 13)^{37}$

\begin{tabular}{|c|c|c|c|c|c|}
\hline & DE & PARA & EM & $\varnothing$ & Total \\
\hline$(\mathrm{S} 4)$ & $52-98,1 \%$ & $01-0,9 \%$ & - & - & 53 \\
\hline$(\mathrm{S} 13)^{38}$ & $33-78,5 \%$ & $04-9,5 \%$ & $05-12 \%$ & - & 42 \\
\hline TOTAL & $89,5 \%$ & $5,25 \%$ & $5,25 \%$ & - & 95 \\
\hline
\end{tabular}

Depreendemos da tabela acima que o uso de preposição nesse tipo de estrutura é categórico. O preenchimento com a preposição de foi o mais alto, acontecendo em 89,5\% dos casos. A preposição para aparece com 5,25\% dos preenchimentos, da mesma forma que a preposição em. Esse resultado atesta a vinculação de de + nome observada no capítulo precedente.

São exemplos de preenchimento com preposição de em S4:

(117) A probabilidade de_cair um avião é uma em um milhão.

(118) A probabilidade de_acertar a alternativa é uma em um milhão.

São exemplos de preenchimento com preposição de em S13:

(119) A dificuldade de se importar diesel é avaliada pelos economistas.

(120) A dificuldade de_arranjar emprego é avaliada pelos economistas.

\footnotetext{
${ }^{36}$ Nesta tabela estão incluídos sujeitos [+DET] e [-DET] para verbos infinitivos.

${ }^{37}$ Em S4, houve 3 preenchimentos com "de que"” e, em S13, houve 5 com "que". Ambos ativando [+FIN]. Os exemplos estão arrolados abaixo:

S13 - A dificuldade que as empresas tem para crescer é avaliada pelos economistas.

A dificuldade que é a situação brasileira é avaliada pelos economistas.

A dificuldade, que é grande, é avaliada pelos economistas.

A dificuldade que enfrentamos hoje é avaliada pelos economistas.

A dificuldade que se tem para administrar o próprio dinheiro é avaliada pelos economistas.

S4 - A probabilidade de que isto se quebre é uma em um milhão.

A probabilidade de que isso aconteça é uma em um milhão. (Esta sentença ocorreu duas vezes)

${ }^{38} \mathrm{Em} \mathrm{S13}$, houve, ainda, 9 respostas que não preenchiam a lacuna com uma oração como fora pedido.
} 
Note que a tabela 12 não computa ainda a presença de se junto à preposição. Com o intuito de verificar se a preposição de acionaria o uso de se, utilizamos a sentença $\mathrm{S} 9$, a qual apresenta a preposição de como item dado:

(121) A chance de_conseguir um intercâmbio é mínima.

Ainda que o item preposicional estivesse presente, este não barrou a possibilidade de preenchimento com uma estrutura [+FIN]. Ocorreram 4 preenchimentos com de que, como vemos nos exemplos abaixo:

(122) A chance de que isso aconteça é mínima.

(123) A chance de que ela passe por isto sem traumas é mínima.

O próximo passo foi produzir um quadro com o preenchimento da posição de sujeito da oração encaixada de S9. Assim, descartamos os 4 preenchimentos com de que, bem como desprezamos uma resposta que não atendeu ao especificado no exercício, isto é, o informante não preencheu a lacuna com uma oração. Totalizamos 51 respostas válidas, das quais 29 foram preenchidas com sujeitos [-DET].

Observamos a realização plena ou nula da posição de sujeito do V-FIN, complemento de nome. Excluímos, assim, os casos de sujeito [+DET], porque a posição de sujeito dessas formas verbais era categoricamente plena, com itens lexicais ou pronomes tônicos. Comecemos com S9 (A chance de...):

Tabela 13 - PREENCHIMENTO DA POSIÇÃO DE SUJEITO (S9)

\begin{tabular}{|c|c|c|c|}
\hline \multicolumn{4}{|c|}{$[$-DET] } \\
\hline$\varnothing$ & PRONOME & SE & TOTAL \\
\hline $19-65,5 \%$ & $04-13,8 \%$ & $6-20,7 \%$ & 29 \\
\hline
\end{tabular}

Ainda que o se seja usado para marcar a leitura indeterminada do sujeito referencial [-FIN], os resultados apontam a preferência pela forma $\varnothing$, com $65,5 \%$ das ocorrências. Segue-se o se com $20,7 \%$ e pronome tônico com $13,8 \%$. 
Abaixo, temos exemplos de cada um dos preenchimentos verificados:

$\varnothing-[-\mathrm{DET}]$

(124) A chance de _encontrar um grande amor e verdadeiro é mínima.

\section{PRONOME TÔNICO [-DET]}

(125) A chance de você ganhar na megasena é mínima.

\section{SE [-DET]}

(126) A chance de se conseguir dar aula na USP é mínima.

Em seguida, usamos o mesmo procedimento para verificar presença de preposição e preenchimento da posição de sujeito nas sentenças S4 e S13. Em S4 (A probabilidade...), dos 56 testes elaborados, foram descartadas 7 respostas que não atendiam ao especificado no enunciado do teste ${ }^{39}$, o que nos fez selecionar apenas 49 respostas. Dessas, 30 respostas preenchiam a posição de sujeito com elementos [-DET]. Obtivemos os seguintes resultados:

Tabela 14- PREENCHIMENTO DA POSIÇÃO DE SUJEITO (S4)

\begin{tabular}{|c|c|c|c|}
\hline \multicolumn{4}{|c|}{$[$-DET] } \\
\hline$\varnothing$ & PRONOME & SE & TOTAL \\
\hline $25-83,4 \%$ & $01-3,3 \%$ & $4-13,3 \%$ & 30 \\
\hline
\end{tabular}

Na posição de sujeito do verbo [-FIN], complemento do nome possibilidade, o uso de $\varnothing$ tem predominância alta sobre as demais formas $(83,4 \%)$, seguido do se $(13,3 \%)$ e do pronome tônico (3,3\%), na leitura indeterminada. Abaixo, elencamos as ocorrências em S4:

$\varnothing[-\mathrm{DET}]$

(127) A probabilidade de _pegar a doença é uma em um milhão.

\footnotetext{
${ }^{39}$ Lacunas não preenchidas com uma oração.
} 


\section{PRONOME TÔNICO [-DET]}

(128) A probabilidade de você ser o vencedor é uma em um milhão.

\section{SE [-DET]}

(129) A probabilidade de se achar uma agulha em um palheiro é uma em um milhão.

Quanto ao preenchimento por preposição, todas as sentenças foram marcadas pela preposição de, com exceção de um caso, preenchido com a preposição para. À preposição para, seguiu-se o elemento nulo:

(130) A probabilidade para _ alcançar tal propósito é uma em um milhão.

Mantivemos o mesmo tipo de análise em S13 (A dificuldade...), descartando 24 respostas inválidas. Houve 25 preenchimentos com elementos [-DET]:

\section{Tabela 15- PREENCHIMENTO DA POSIÇÃO DE SUJEITO (S13)}

\begin{tabular}{|c|c|c|c|}
\hline \multicolumn{4}{|c|}{$[-\mathrm{DET}]$} \\
\hline$\varnothing$ & PRONOME & SE & TOTAL \\
\hline $20-80 \%$ & - & $5-20 \%$ & 25 \\
\hline
\end{tabular}

$\mathrm{Na}$ leitura indeterminada, não houve preenchimento por pronome tônico. O elemento nulo manteve-se na preferência de preenchimento $(80,0 \%)$, seguido do se $(20,0 \%)$.

$\varnothing[-\mathrm{DET}]$

(131) A dificuldade de_manter o superávit é avaliada pelos economistas.

SE [-DET]

(132) A dificuldade de se importar diesel é avaliada pelos economistas. 
Em S13, além da preposição de, tivemos 3 preenchimentos com a preposição para e 3 ocorrências com a preposição $\mathrm{em}$. Esta última figurou apenas junto a $\varnothing$, enquanto para ocorreu na seguinte distribuição: item lexical (1), Ø (1) e se (1). Ao agrupar os resultados encontrados em S4 e S13, constatamos que a maior incidência é de preposição $d e$.

Quanto à referencialidade, constatou-se que a indeterminação é preferencialmente marcada com Ø, seguido de se e do pronome tônico. Assim, produzimos a seguinte tabela para compararmos as estratégias de indeterminação nas três sentenças:

Tabela 16 - ESTRATÉGIAS DE INDETERMINAÇÃO (S9-S4-S13)

\begin{tabular}{|c|c|c|c|}
\hline \multicolumn{4}{|c|}{$[$-DET] } \\
\hline & $\varnothing$ & SE & PRONOME \\
\hline S9 - Chance de & $65,5 \%$ & $20,7 \%$ & $13,8 \%$ \\
\hline S4- Probabilidade & $83,4 \%$ & $13,3 \%$ & $3,3 \%$ \\
\hline S13 - Dificuldade & $80 \%$ & $20 \%$ & - \\
\hline
\end{tabular}

O índice de ocorrência de se manteve-se estável, sendo menor apenas em S13 com 13,3\%, única sentença na qual não figurou o pronome tônico.

\subsubsection{COMPLETIVAS DE ADJETIVO}

No grupo de completivas de adjetivo, contrapusemos a sentença S6, estrutura com $\mathrm{o}$ item preposicional dado à $\mathrm{S} 12$, sem o item preposicional.

(S6) É impossível de...

(S12) É difícil... 
Mantendo o paralelismo de análise, primeiramente, em S12 (É difícil...), observamos se houve ou não o preenchimento por preposição, e qual o item preposicional usado. Obtivemos os seguintes resultados:

Tabela 17- PREPOSIÇÃO ${ }^{40}$ X PREENCHIMENTO DO SUJEITO (S12)

\begin{tabular}{|c|c|c|c|}
\hline & $\varnothing$ & SE & Total \\
\hline DE & - & 01 & $01-1,9 \%$ \\
\hline$\varnothing$ & 49 & 03 & $52-98.1 \%$ \\
\hline TOTAL & $49-92,5 \%$ & $04-7,5 \%$ & 53 \\
\hline
\end{tabular}

Em S12, tivemos 52 respostas sem o uso da preposição, sendo 49 com a marcação $\varnothing$ de sujeito e apenas 3 com se. Observemos alguns exemplos com Ø:

$\varnothing$

(133) É difícil_saber o que escrever agora.

(134) É difícil_ não repetir palavras.

(135) É difícil_ ficar indiferente às eleições.

Vejamos que o se, nos únicos três casos encontrados, ativa leitura reflexiva e não de indeterminação:

SE

(136) É difícil não se render às tentações.

(137) É difícil se esquecer alguém que foi importante para você.

(138) É difícil se concentrar em meio a multidão.

O único caso de se [-DET] é o que é precedido de preposição e apresenta um verbo inacusativo (morar):

\footnotetext{
${ }^{40} \mathrm{Em} \mathrm{S12}$, houve um preenchimento com "que", ativando [+FIN]. Vejamos:

É difícil que haja outra discussão sobre esse tema.

Houve um único teste que não foi preenchido com uma oração:

É difícil demais.
} 
(139) É difícil de se morar nessa casa.

O adjetivo "difícil" não acionou o uso da preposição na quase totalidade dos casos $(98,1 \%)$. Entretanto, é interessante observar que o único caso com preposição ativou a presença de um se.

Passemos, então, à observação de S6 (É impossível de...), sentença na qual era dada a preposição:

Tabela 18- PREENCHIMENTO DA POSIÇÃO DE SUJEITO (S6) ${ }^{41}$

\begin{tabular}{|c|c|c|c|}
\hline$\varnothing$ & SE & $\begin{array}{c}\text { PRONOME } \\
\text { TÔNICO }\end{array}$ & TOTAL \\
\hline $26-63,4 \%$ & $14-34,1 \%$ & $01-2,5 \%$ & 41 \\
\hline
\end{tabular}

A tabela nos mostra que, com a preposição dada, o número de preenchimentos com se aumentou substancialmente, chegando aos 34,1\%. No entanto, a marcação Ø manteve-se em primeiro lugar com 63,4\% das ocorrências. O pronome tônico ficou com 2,5\%, apresentando apenas uma ocorrência.

\section{$\varnothing$}

(140) É impossível de_averiguar os fatos.

(141) É impossível de _ prever acidentes aéreos.

SE

(142) É impossível de se entender a teoria marxista.

(143) É impossível de se pensar nisso sem sentir incômodos.

\section{PRONOME TÔNICO}

(144) É impossível de você achar respostas certas.

\footnotetext{
${ }^{41}$ Foram descontadas duas respostas que não preenchiam a lacuna com uma oração. Houve uma resposta em branco, uma preenchida com verbo [+FIN] e duas preenchidas com sujeito [+DET].
} 
Interessante observar que, em 9 respostas, o informante riscou a preposição. Nesses casos, assim como ocorreu em S12, a marcação Ø de preposição ativou Ø na marcação do sujeito. Vejamos alguns exemplos:

(145) É impossível (de)_sonhar duas vezes o mesmo sonho.

(146) É impossível (de)_entender trigonometria.

Da comparação entre as estratégias de indeterminação encontradas nas duas sentenças completivas de adjetivo analisadas, produzimos a seguinte Tabela:

Tabela 19 - ESTRATÉGIAS DE INDETERMINAÇÃO (S12-S6)

\begin{tabular}{|c|c|c|c|}
\hline & $\varnothing$ & SE & PRONOME \\
\hline DIFÍCIL & $49-92,5 \%$ & $04-7,5 \%$ & - \\
\hline IMPOSSÍVEL DE & $26-63,4 \%$ & $14-34,1 \%$ & $01-2,5 \%$ \\
\hline
\end{tabular}

Constata-se que o Ø predomina na leitura [-DET] do sujeito de V-FIN. Pelo resultado encontrado em $\mathrm{S} 6$, o se é acionado na presença de preposição, sentença na qual a preposição de era um item dado. 


\title{
4.3. CONSIDERAÇÕES FINAIS DO CAPÍTULO
}

Assim, conseguimos abstrair algumas generalizações sobre a referencialidade do sujeito nas orações estudadas. Primeiramente, sobre as adverbiais, observamos que $\varnothing$ marca sujeito [+DET], enquanto se marca sujeito [-DET]. Como podemos esquematizar no quadro abaixo:

\author{
ORAÇÕES ADVERBIAIS \\ $\varnothing$ marca sujeito [+DET] \\ SE marca sujeito [-DET]
}

A tendência, nas orações adverbiais, é a correlação entre $\varnothing$ na oração encaixada e preenchimento de sujeito referencial [+DET] na matriz, instaurando coindexação entre o $\varnothing$ da encaixada com o sujeito da matriz. O sujeito do V-FIN é se se o sujeito da matriz for [-DET]. Não havendo coindexação entre os dois sujeitos, o V-FIN passa a ter leitura $[-\mathrm{DET}]{ }^{42}$

Nas orações completivas de nome e adjetivo, ao contrário das orações adverbiais, $\varnothing$ marca sujeito [-DET], enquanto se marca sujeito [-DET] na presença de preposição:

\section{ORAÇÕES COMPLETIVAS DE NOME/ADJETIVO \\ $\varnothing$ marca sujeito [-DET] \\ SE marca sujeito [-DET] na presença de preposição}

\footnotetext{
${ }^{42}$ Não foi atestada a presença de pronome tônico nas matrizes dessas orações, pois não foi prevista a elicitação de orações adverbiais, mas sim de orações matrizes para as encaixadas propostas.
} 
No caso das completivas, ainda que o pronome se seja uma estratégia para marcar a indeterminação do sujeito, a forma nula de sujeito de verbos [-FIN] prevalece nas construções de complemento de nome com essa mesma função. Além disso, nessas estruturas, o sujeito indeterminado de verbos [-FIN] pode ser um pronome tônico.

Como nas completivas de nome e de adjetivo não se criou um ambiente propício para a coindexação entre o sujeito do V-FIN e o sujeito da matriz, devido à ausência de um antecedente, o elemento Ø ativou a leitura indeterminada. Compare (a) e (b) de 147:

(a) É impossível_chegar no horário.

(b) A Maria ${ }_{i}$ acha que é impossível_ij/j(top)/arb chegar no horário.

Num contexto em que ocorre antecedente na sentença, o sujeito nulo do V-FIN teria interpretação ambígua. Já em (a), como não há nenhum elemento nominal que possa servir de antecedente, é detonada uma leitura [-DET] do sujeito nulo, como se tivéssemos uma estrutura do tipo (148):

(148) Diz-se [-DET] $_{\text {que é impossível _ [-DET] }}$ chegar no horário.

Consideramos que os resultados encontrados no teste de produção reafirmaram os resultados obtidos nas análises produzidas no Capítulo 3. Os testes ainda nos permitiram discutir a questão da referencialidade e verificar a relação entre indeterminação da matriz e da encaixada que recebe o se. Outro elemento importante foi confirmar que é a preposição que licencia a inserção de se em construções com verbos [-FIN]. 


\section{CONSIDERAÇÕES FINAIS}




\section{CONSIDERAÇÕES FINAIS}

A perda da propriedade do sujeito nulo no PB (Duarte 2000, entre outros) e a formação da série pronominal fraca (Kato 2000) têm propiciado a realização plena da posição do sujeito com um pronome fraco, seja com interpretação determinada, seja com interpretação indeterminada ${ }^{43}$ de verbos finitos. O uso de diferentes formas pronominais para a posição de sujeito, inclusive com referência indeterminada (em franca dissonância com as gramáticas normativas), tira a exclusividade do pronome se dessa função com verbos finitos.

Os resultados do teste de produção com verbos inacusativos em orações adverbiais com V-FIN mostraram que o sujeito nulo tem privilegiadamente a interpretação determinada, carregando o índice de correferencialidade com a sentença matriz. No confronto com verbos finitos, os não-finitos asseguram interpretação referencial determinada ao sujeito nulo. Já a interpretação referencial indeterminada passa a ser marcada com o pronome se. Ou seja, o pronome se mantém a função de indeterminar a referencialidade do sujeito, mas esta função é deslocada de uma estrutura sintática [+FIN] para [-FIN], conforme já postulara Galves (1987).

É provável que a mudança parta de verbos inacusativos porque $s e V$-FIN não permitiria a leitura passiva. Assim, recuperamos que a mudança envolvendo a entrada de se em estruturas [-FIN] parte da reanálise de estruturas passivas como ativas, fato que propicia a aposição do se também junto a esses verbos. Essa novidade ratifica a sua entrada como estratégia de indeterminação.

Ao estabelecer uma comparação entre o PB e o PE, vemos que, neste último, como apresenta um sistema flexional rico, não há a necessidade de preenchimento da posição de sujeito, pois este já vem marcado na flexão. O PB, por sua vez, como sugere Kato (2000), por ter uma flexão pobre, ativa a marcação da posição de sujeito do verbo [+FIN]. Sendo assim, no PB, a tendência é a realização plena do sujeito, incluindo a

\footnotetext{
${ }^{43}$ A não-referencialidade também tem sido marcada com formas pronominais fracas, como é o caso das construções existenciais em que aparece 'você'. Ex: Hoje você tem prédios em todas as capitais.)
} 
posição de sujeito de verbos [-FIN], em contraposição ao PE que apresenta o morfema Ø no verbo [-FIN] indicando a indeterminação.

Observamos, ainda, que o se emerge em sentenças [-FIN] em contextos em que uma preposição está presente. Identificamos três tipos de preposição e as diferenciamos através de traços + funcional. A preposição $[+\mathrm{F}]$ é $d e$, que ocorre majoritariamente com elementos nominais, completando-os, de modo que se comporta como um X de CP. Assumimos, com Mioto e Kato (op.cit), que o CP infinitivo necessita de uma preposição funcional para fechar sua projeção estendida, sendo um elemento forte para a introdução do se. A preposição [-F] é $a$, que, em contrapartida, não é precedida por nenhum elemento, encontrando-se em condição de adjunção no nível XP. A preposição para, por sua vez, tem como antecedente a categoria nome ou elemento nulo, isto é, está entre $\mathrm{X}^{\mathrm{o}} \mathrm{e}$ XP. Por ter um comportamento diferenciado, podemos dizer que este elemento está entre complemento e adjunto. Dentre os três tipos elencados, a preposição $[+\mathrm{F}]$ é a que mais privilegiou o uso de se.

O presente estudo procurou determinar os contextos mais favorecedores da inserção de se em sentenças infinitivas e promover uma análise dessa inovação no sistema de indeterminação do PB. 
REFERÊNCIAS BIBLIOGRÁFICAS 


\section{REFERÊNCIAS BIBLIOGRÁFICAS}

BECHARA, E. (1988) Moderna Gramática Portuguesa. 32ed. São Paulo: Nacional.

BRITTO, H.S. (1994) Reduzidas Gerundivas: Teoria do Caso e Inversão Verbo-Sujeito.

Dissertação de Mestrado, Universidade Estadual de Campinas, SP.

CAVALCANTE, Silvia R. (1999) A indeterminação do sujeito na escrita padrão: a imprensa carioca nos séculos XIX e XX. Dissertação de Mestrado, Faculdade de Letras/ UFRJ, Rio de Janeiro.

CAVALCANTE, Silvia R. (2002) Formas de Indeterminação na Imprensa Carioca dos Séc.XIX e XX. In: Para a História do Português Brasileiro Vol.III - Novos Estudos, São Paulo: Humanitas/ FFLCH/USP.

CHOMSKY, N. (1981) Lectures on Government and Binding, Dodrecht: Foris. (1986a) Knowledge of Language: its nature, origin and use. New York:

Praeger. (1986b) Barriers. Cambridge, Mass.: MIT Press.

(1988) Language and Problems of Knowledge. The Manágua Lectures. Cambridge, Mass.: MIT Press.

CHOMSKY, N., LASNIK (1991) Principles and Parameter Theory. In: JACOBS, A.S. et al (Eds.) Syntax: An International Handbook of Contemporary Research. Berlin: Walter dee Gruyter.

CUNHA,C. \& CINTRA, L.F.L. (1985) Nova Gramática do Português Contemporâneo. 2 ed. Rio de Janeiro: Nova Fronteira.

DUARTE, M.E.L. (1993) Do pronome nulo ao pronome pleno: a trajetória do sujeito do português do Brasil. In: ROBERTS, I.; KATO, M. (Orgs.), Português brasileiro: uma viagem diacrônica. Campinas: Editora da Unicamp, pp.107-28.

(2000) The loss of the 'Avoid Pronoun' Principle in Brazilian Portuguese.

In: KATO, M.A.; NEGRÃO, E.V. (Eds.). Brazilian Portuguese and the Null Subject Parameter. Vervuert, Frankfurt.

(2002) Construções com se apassivador e indeterminador em anúncios do século XIX. In: ALKIMIM, T. (Org.) Para a História do Português Brasileiro Vol.III Novos Estudos, São Paulo: Humanitas/FFLCH/USP, pp.155-195. 
DUARTE, M.E.L., LOPES, C.R.S. (2002) Realizaram, Realizou-se ou Realizamos...?. In: DUARTE, M.E.L.; CAlloU, D. (Org.). Para a História do Português Brasileiro Vol. IV: Notícias de corpora e outros estudos, Rio de Janeiro: UFRJ/Letras - FAPERJ, pp. 155-165.

ELISEU, A.M.G.S. (1984) Verbos ergativos do português: descrição e análise. Dissertação de Mestrado. Universidade de Lisboa.

GALVES, C. (2001) A sintaxe do português brasileiro. In: Ensaios sobre as gramáticas do português. Campinas, São Paulo: Editora da Unicamp.

HAEGEMAN, L.(1994) Introduction to Government and Binding Theory. Oxford: Blackwell.

JACKENDOFF (1972) Semantic Interpretation in Generative Grammar. 2.ed.Cambridge, Mass.: MIT Press.,1975.

KATO, M.A. (2000) The partial Pro-Drop Nature and the Restricted VS Order in Brazilian Portuguese. In: KATO, M.A.; NEGRÃO, E.V. (Eds.). Brazilian Portuguese and the Null Subject Parameter. Vervuert, Frankfurt.

LABOV, W. (1982) Building on empirical foundations. In: Perspectives on historical linguistics. John Benjamins Publishing Company, Amsterdam/ Philadelphia.

MARTINS, A.M. (2005) Passive and impersonal se in the history of Portuguese. In: PUSH, C. D., KABATEK, J., RAIBLE, W. (eds.). Romance corpus linguistics II: corpora and diachronic linguistics. Tübigen: Gunter Narr Verlag, pp. 411-430.

MAURER JR., T.H. (1968) O infinitivo flexionado português. Companhia Ed. Nacional. MIOTO, C. et al. (2005) Novo Manual de Sintaxe, 2.ed.rev . Florianópolis: Insular. MIOTO,C \& KATO, M.A (2002) Aspectos sintáticos da subordinação sentencial. In: ABAURRE, M.B.M. \& RODRIGUES, A.C.S. (Orgs.). Gramática do Português Falado v.8-Novos estudos descritivos, Editora Unicamp, p.379-412.

NARO, A.J. (1976) The genesis of the reflexive impersonal in Brazilian Portuguese: a study in syntactic change as a surface phenomenon. In: Language 52, 779-811.

NUNES, J.M. (1990) O famigerado se: uma análise sincrônica e diacrônica das construções com se apassivador e indeterminador. Dissertação de Mestrado em Lingüística. São Paulo: Unicamp. 
(1991) Se apassivador e se indeterminador: o percurso diacrônico no português brasileiro. In: Cadernos de Estudos Lingüisticos, 20 jan/jun, Unicamp.

(1995) Ainda o famigerado se. In: DELTA 11 (2), 201-240.

OLIVEIRA, M. (2003) Adjuntos e Complementos Verbais Introduzidos pela Preposição 'A'. USP (mimeo).

RADFORD, A. (2004) Minimalist Syntax - Exploring the structure of English. Cambridge.

RAPOSO, E.P.(1992) Teoria da Gramática. A faculdade da Linguagem. Lisboa: Editorial Caminho.

RIZZI, L. (1995) The Fine Structure of Left Periphery. In: HAEGMAN,L (ed.) Elements of Grammar. Kluwer Academic Publishers, pp.281-337.

ROCHA, M.A.F. (1989) Complementizadores no português do Brasil: uma abordagem inter- e intra-sistêmica. In: F. TARALLO (org.) Fotografias Sociolingüisticas. Campinas, SP: Pontes; Editora da Universidade Estadual de Campinas. P. 141-63.

SAID ALI, M. (1964) Gramática Secundária e Gramática Histórica da Lingua Portuguesa. São Paulo: Editora Universidade de Brasília. (2001) Gramática Histórica da Língua Portuguesa. 8. ed. ver. e atualizada

Por Mário Eduardo Viaro - São Paulo: Companhia Melhoramentos; Brasília/DF.

SOUZA, L.R.F. (1998) A Teoria do Controle: O Estudo do Controle em Estruturas de Objeto Duplo do Português Brasileiro. Dissertação de Mestrado UNESP - FCL/CAr.

TARALLO, F. (2001) A pesquisa sociolingüiśtica. São Paulo: Ed. Ática.

WEINREICH,U., LABOV,W \& HERZOG, M. (1968) Empirical Foundation for a Theory of Language Change. In. LEHMANN, W.P. \& MALKIEL Y. (eds.) Directions for Historical Linguistics. Austin: University of Texas Press. 